

\section{DAFTAR ISI}

Muchamad Arif, Elok Damayanti, Dwi Ayu Lusia

Pengaruh Penerapan Elina Mata Kuliah Business English Untuk Kelas Mahasiswa Pekerja

Di Universitas Narotama

Umi Zulfah

Penerapan Gerakan Senam Ceria Untuk Meningkatkan Minat Siswa Dalam Kegiatan

Fisik Motorik Kelompok B Di Pos Paud Terpadu Kartini Kota Surabaya

Varia Virdania Virdaus

The Improvement Of English Writing And Students' Motivation Through Brainstorming

Endah Hendarwati, Wahono, Aris Setiawan

Implementasi Nilai Kejujuran Pada Anak Usia Dini Melalui Media Ular Tangga

Dian Anggraini, Andini Dwi Arumsari

Permainan Monyet Dan Pohon Untuk Menstimulus Perkembangan Anak Usia Dini

Lianatus Shofia, Valentine Aqwarinna Gempita, Nopitasari, Muchamad Arif

Penerapan Applikasi Edukasi Komputer Untuk Meningkatkan Hapalan Abjad

Di Tk Yapita Surabaya 
PENGARUH PENERAPAN ELINA MATA KULIAH BUSINESS ENGLISH UNTUK KELAS MAHASISWA PEKERJA DI UNIVERSITAS NAROTAMA

\author{
Muchamad Arif ${ }^{1}$, Elok Damayanti ${ }^{2}$, Dwi Ayu Lusia ${ }^{3}$ \\ ${ }^{1,2}$ Program Studi Manajemen, Fakultas Ekonomi dan Bisnis \\ ${ }^{3}$ Program Studi Sistem Informasi, Fakultas Ilmu Komputer
}

\author{
${ }^{1}$ muchamad.arif@narotama.ac.id \\ 22elok.damayanti@narotama.ac.id \\ 3dwi.ayu@narotama.ac.id
}

\begin{abstract}
Abstrak: Universitas Narotama memiliki dua kelas mahasiswa pekerja yakni kelas B dan kelas C. Kelas B mendapatkan pembelajaran klasik yakni tatap muka. Sedangkan, Kelas C mendapatkan pembelajaran klasik dan eleaning, yang disebut dengan elina. Penelitian ini adalah quasi experimental. Penulis menguji skor dalam mata kuliah business English pada ujian tengah semester, ujian akhir, tugas, kehadiran dan total skor untuk semester dengan menggunakan metode t-test. Hasilnya adalah tidak ada perbedaan yang signifikan antara kelas pembelajaran campuran dan kelas pembelajaran klasik untuk total skor dan kehadiran. Di sisi lain, secara khusus ada dua perbedaan yang signifikan. Pertama, dalam nilai tengah semester, kelas pembelajaran campuran memiliki nilai yang lebih rendah daripada kelas pembelajaran klasik. Kedua, dalam ujian akhir dan nilai tugas, kelas pembelajaran campuran memiliki nilai lebih tinggi daripada kelas pembelajaran klasik.
\end{abstract}

Kata Kunci: e-lina, mahasiswa kelas pekerja, business English, t-test

Abstract: Narotama University has two classes for employee class. They are Class B and Class C. Class B get classic learning. On the other hand, Class C get classic learning and e-learning, it is called as Elina. This research is quasi experimental. The author tests the scores in the business English course on the midterm, final exam, assignments, attendance and total scores for the semester using the t-test method. The result is that there is no significant difference between mixed learning classes and classical learning classes for total scores and attendance. On the other hand, specifically there are two significant differences. First, in midterm grades, mixed learning classes have lower grades than classical learning classes. Second, in the final 
examination and assignment grades, mixed learning classes have higher grades than classical learning classes.

Key words: e-lina, employee class, business English, t-test

\section{PENDAHULUAN}

Saat ini siswa-pekerja membutuhkan waktu belajar yang fleksibel, yang tidak hanya belajar secara langsung, tetapi juga membutuhkan pembelajaran online, di mana siswa secara mandiri menyelesaikan komponen online kursus di luar kelas. Dalam hal ini, waktu di kelas dapat diganti atau ditambah dengan pengalaman belajar online, dan siswa akan belajar tentang topik yang sama atau berbeda secara online seperti yang mereka lakukan di kelas misalnya, pengalaman belajar online dan di-orang akan paralel dan melengkapi satu sama lain. Universitas Narotama memiliki dua pilihan metode pembelajaran untuk kelas karyawan, yaitu pembelajaran campuran (42,9\% online dan $57,1 \%$ pembelajaran perorangan) dan pembelajaran klasik (100\% pembelajaran perorangan). Pembelajaran online dapat menjadi bagian komponen kecil dari kursus berbasis kelas. Dalam hal ini, siswa dapat bekerja secara mandiri pada pelajaran online, proyek, dan tugas di rumah atau di tempat lain, dan secara berkala bertemu dengan guru untuk meninjau kemajuan pembelajaran mereka, mendiskusikan pekerjaan mereka, mengajukan pertanyaan, atau menerima bantuan dengan konsep yang sulit, juga mendiskusikan materi baru . Melalui model penelitian oleh Gupta dan Peckham, ia mengatakan bahwa teknologi dapat membantu dalam meningkatkan motivasi siswa dalam belajar, tetapi tetap saja faktor-faktor itu kembali ke individu itu sendiri. Lembaga atau manajemen atau organisasi harus memastikan bahwa gaya belajar harus bervariasi untuk menyesuaikan siswa, untuk mendapatkan minat siswa, yang cukup sulit dan menantang. Itulah sebabnya mengapa melalui pembelajaran campuran seperti yang disarankan oleh Khan, itu menunjukkan bahwa itu bisa sangat membantu dalam melibatkan siswa (atau kebanyakan dari mereka) untuk belajar dan membantu mereka untuk memahami lebih baik di kelas, karena mengadaptasi gaya belajar gaya yang berbeda dan mengadopsi teknologi seperti elemen multimedia di kelas.

\section{LANDASAN TEORI}

Pembelajaran in-person adalah bentuk interaksi instruksional yang terjadi "secara pribadi" dan secara real time antara guru dan siswa atau di antara rekan dan rekan kerja. Sebelum munculnya teknologi audio, video, dan internet yang memungkinkan orang untuk berinteraksi 
dari lokasi yang berbeda dan pada waktu yang berbeda, semua interaksi pembelajaran terjadi, karena kebutuhan, di tempat yang sama dan pada saat yang sama. Definisikan pembelajaran Online, ini mengacu pada interaksi pelajar dengan konten dan / atau orang-orang melalui internet untuk tujuan pembelajaran. Belajar dapat menjadi bagian dari program formal atau hanya sesuatu yang dipelajari oleh peserta didik untuk kepentingan mereka sendiri. Kami membatasi konsep pembelajaran online kami untuk belajar yang sesuai dengan tujuan mencari informasi atau belajar untuk melakukan sesuatu, bahkan jika itu adalah cara bermain game online. Kami tidak menyertakan pembelajaran insidentil yang mungkin terjadi dalam proses mengejar sasaran lain (misalnya, apa yang dapat dipelajari tentang berbagai produk dalam proses belanja). Kedua instruktur mengarahkan guru dan sumber daya desain untuk mengajar tanpa kehadiran seorang guru memenuhi definisi pembelajaran online jika mereka dilakukan melalui internet. Blended Learning adalah gabungan pengalaman belajar tatap muka dan online yang bijaksana. Kunci dasarnya adalah bahwa komunikasi lisan tatap muka dan komunikasi tertulis online secara optimal disatukan sedemikian rupa sehingga kekuatan masing-masing dicampur menjadi pengalaman belajar yang unik sesuai dengan konteks dan tujuan pendidikan yang dimaksudkan. Meskipun konsep blended learning mungkin nampak secara intuitif dan sederhana, aplikasi praktisnya lebih kompleks. Yang paling penting, pembelajaran campuran adalah desain ulang mendasar yang mengubah struktur, dan pendekatan, pengajaran dan pembelajaran. Asumsi utama dari desain pembelajaran terpadu adalah: secara sadar mengintegrasikan pembelajaran tatap muka dan online; secara fundamental memikirkan ulang desain kursus untuk mengoptimalkan keterlibatan siswa; dan merestrukturisasi dan mengganti jam kontak kelas tradisional.

\section{METODOLOGI}

Penelitian ini menggunakan quasi experimental. Penelitian ini mempunyai dua kelompok, yakni kelompok kontrol dan eksperimental (Ary: 1985, Azwar: 1999, Sukardi: 2004). Penelitian ini dilaksanakan di Universitas Narotama pada semester genap tahun ajaran 20172018. Pengambilan sample menggunakan metode purposive sampling karena peneliti menentukan kelompok yang mereka pilih untuk melakukan penelitian (Ary: 1985, Azwar: 1999, Sukardi: 2004). Samplenya adalah mahasiswa narotama yang mengambil matakuliah business English di kelas B dan kelas C. Dalam penelitian ini, kelas kontrol adalah kelas yang mendapatkan perkuliahan dengan metode pembelajaran klasik, yakni kelas B. Sedangkan kelas experiment yaitu siswa diajarkan menggunakan e-lina. Data yang diambil adalah tiga 
nilai mahasiswa, yaitu: nilai tengah semester, nilai ujian akhir, dan nilai tugas. Mereka diuji dengan metode t-test.

\section{HASIL DAN DISKUSI}

Rata-rata dan standar deviasi ujian tengah semester, ujian akhir, tugas, kehadiran dan total skor untuk semester dapat digambarkan seperti di bawah ini.
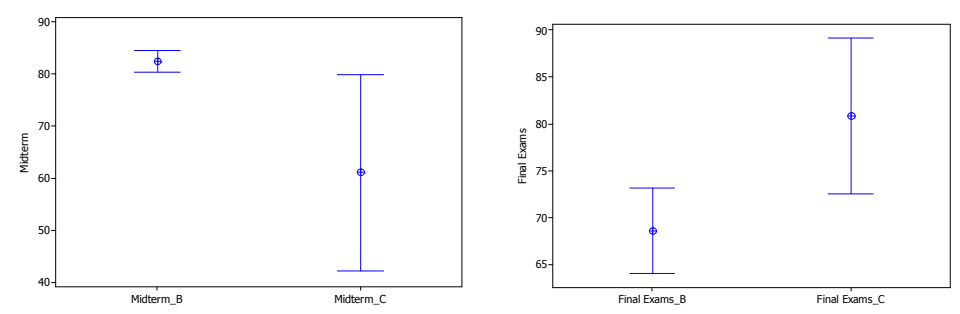

a.UTS

b. UAS

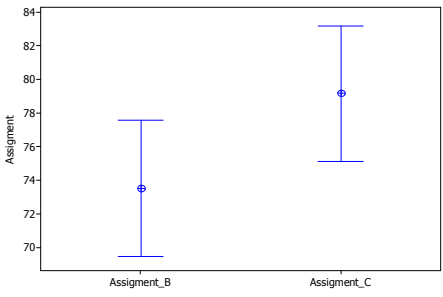

c. Tugas

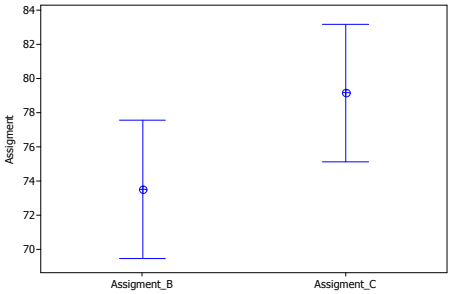

d. Kehadiran

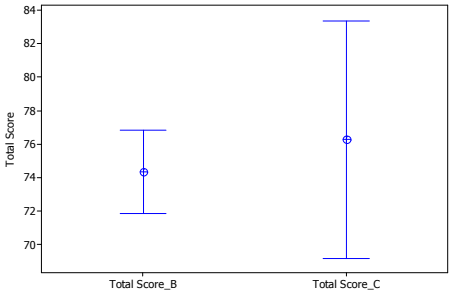

e. Nilai Total

\section{Gambar 1 - Nilai Semester}

Berdasarkan Gambar 1, ada persimpangan antara Kelas B dan C, artinya tidak ada perbedaan antara Kelas B dan C. Namun perhitungan harus diuji lagi dengan menggunakan dua sampel independen t-test. Di bawah ini adalah hasil untuk menguji persamaan varians dan t-test.

Tabel 1 - Uji Persamaan Varian dan T-test

\begin{tabular}{lcrrrrr}
\hline \multirow{2}{*}{ Variabel } & \multicolumn{2}{c}{ Equality Variance's Test } & \multicolumn{3}{c}{ Two Independent Sample T-test } \\
& F & P-value & Conclusion & \multicolumn{1}{c}{ T } & P-value & Conclusion \\
\hline UTS & 0.05 & 0.000 & Perbedaan Sig & 2.48 & 0.030 & Perbedaan Sig \\
UAS & 1.18 & 0.812 & Sama & -2.66 & 0.010 & Perbedaan Sig \\
Tugas & 4.00 & 0.017 & Perbedaan Sig & -2.09 & 0.044 & Perbedaan Sig \\
Kehadiran & 1.18 & 0.812 & Sama & 0.67 & 0.503 & Sama \\
Total Score & 0.48 & 0.094 & Sama & -0.68 & 0.501 & Sama \\
\hline
\end{tabular}


Tabel 1 menyimpulkan bahwa ujian tengah semester, ujian akhir, dan tugas memiliki perbedaan antara kelas B dan C. Namun, tidak ada perbedaan dalam kehadiran dan skor total. UTS di kelas B lebih tinggi dari kelas C (berdasarkan Gambar 1). Meskipun, ujian akhir dan tugas di kelas C lebih tinggi dari kelas B. Kondisi ini menunjukkan bahwa siswa di kelas C memiliki waktu untuk beradaptasi sampai ujian tengah semester untuk pembelajaran campuran. Dari sana di kelas C memiliki lebih banyak waktu untuk mengambil tugas dan lebih percaya diri untuk ujian akhir. Di sisi lain, kelas B lebih suka menghadiri kelas tradisional karena mereka memiliki komunikasi lisan tatap muka dengan dosen. Jadi itulah mengapa siswa di kelas B memiliki nilai tengah semester yang lebih tinggi daripada kelas $\mathrm{C}$. Seiring berjalannya waktu, siswa di kelas B memiliki skor penurunan dalam tugas dan ujian akhir, karena siswa harus memberikan banyak upaya untuk menghadiri kelas. Di pagi hari, siswa kelas B harus pergi bekerja dan pada malam hari mereka harus menghadiri kelas, yang pasti sangat lelah.

\section{KESIMPULAN}

Pembelajaran terpadu adalah metode yang bermanfaat yang dapat meningkatkan skor di semester. Ini adalah bukti oleh perbedaan yang signifikan dan siswa di kelas $\mathrm{C}$ memiliki nilai yang lebih tinggi daripada kelas B, baik ujian akhir maupun tugas. Namun, siswa di kelas C membutuhkan waktu adaptasi untuk memahami pembelajaran campuran.

\section{References}

Ary, Donald. 1985. Introduction to Research In Education. New York:CBS College Publishing

Azwar, Saifuddin. 1999. Metode Penelitian. Yogyakarta : Pustaka Pelajar

Garrison, D. Randy. 2007. San Francisco, CA: Jossey-Bass A Wiley Imprint

Means, Barbara. 2014. Learning Online: "When research tells us about whether, when and how". New York: Routledge Taylor \& Francis Group.

Ramakrisnan, Prasanna. 2012. Blended Learning: A Suitable Framework for E-Learning in Higher Education. Universiti Teknologi MARA (UiTM),

Shah Alam, Malaysia: Elsevier Ltd.

Sukardi, 2004. Metode Penelitian Pendidikan. Jakarta: Bumi Aksara

Vai, Marjorie. 2016. Essential of Online Course Design: A Standards-Based Guide. New 
York: Routledge Taylor \& Francis Group 


\title{
PENERAPAN GERAKAN SENAM CERIA UNTUK MENINGKATKAN MINAT SISWA DALAM KEGIATAN FISIK MOTORIK KELOMPOK B DI POS PAUD TERPADU KARTINI KOTA SURABAYA
}

\author{
ABSTRAK \\ Umi Zulfah \\ Fakultas Ilmu Pendidikan, Universitas Narotama, Surabaya \\ Umizulfah1976@gmail.com
}

Pada anak usia dini keaktifan dalam berbagai aktivitas diperlukan bagi pengembangan otot besar dan otot kecil. Di laksanakannya senam ceria sangat membantu perkembangan siswa dalam kegiatan fisik motorik. Tujuan penelitian adalah mendiskripsikan penerapan gerakan senam ceria yang digunakan untuk meningkatkan minat siswa dan menjelaskan penerapan gerakan senam ceria dapat meningkatkan minat siswa. Penelitian ini adalah penelitian tindakan kelas (PTK). Pengumpulan data menggunakan lembar observasi rekapitulasi data peningkatan minat siswa dan dokumentasi foto. Teknik analisis data menggunakan deskriptif kualitatif dan deskriptif kuantitatif prosentase. Hasil penelitian menunjukkan bahwa (1) kondisi awal minat siswa terhadap kegiatan fisik motorik termasuk tendah, setelah diberi penerapan gerakan senam ceria terlihat peningkatan terhadap fisik motorik siswa. (2) Hasil penelitian pada siklus I dan siklus II menunjukkan ada peningkatan dari 54,375\% menjadi 85\% dari rata-rata jumlah siswa sehingga masuk kategori BSH (Berkembang Sesuai Harapan). Dari hasil tersebut bisa disimpulkan bahwa senam ceria dapat meningkatkan minat siswa terhadap kegiatan fisik motorik kelompok B di Pos Paud Terpadu Kartini Kota Surabaya.

Kata kunci : Motorik kasar, senam ceria, PAUD

\begin{abstract}
Early childhood activity in various activities is necessary for the development of large muscles and small muscles. The implementation of cheerful gymnastics is very helpful for student development in physical motor activities. The aim of the study is to describe and outline the students ' interest in the physical motor activity and to decipher the application of the cheerful gymnastics movement can increase student interest. This research is a class action research (PTK). Data collection using an observation sheet recapitulation of student interest increase data and photo documentation. Data analysis techniques used is descriptive qualitative and descriptive quantitative. The results showed that (1) the initial conditions of the students ' interest in physical motor activities included low, after being given the application of cheerful gymnastics movements seen an increase in physical motor students. (2) results of research on cycle I and cycle II Shows there is an increase from $54.375 \%$ to $85 \%$ of the average number of students so it enters the category BSH (growing as expected). From these results can be concluded that the cheerful gymnastics can increase students ' interest in the physical activities of Group B in Pos Paud Terpadu Kartini Surabaya.
\end{abstract}


Keywords : gross Motoric, cheerful gymnastics, early childhood

\section{PENDAHULUAN}

Pada masa perkembangan anak di PAUD pada usia tahun pertama yang disebut usia keemasan (The golden years) yang merupakan masa emas perkembangan anak dan pada usia tersebut anak mempunyai potensi yang sangat besar untuk mengoptimalkan segala aspekaspek perkembangannya yaitu : pembiasaan, bahasa, kognitif, fisik-motorik dan seni. Perkembangan fisik adalah dasar untuk kemajuan perkembangan selanjutnya. Berkenaan dengan perkembangan fisik, Kuhlen dan Thompson (Hurlock, 1956: 101) mengemukakan bahwa: Perkembangan fisik perorangan/peranak meliputi empat aspek, yaitu (1) sistem syaraf, yang begitut mempengaruhi perkembangan kecerdasan dan emosi; (2) otot-otot yang mempengaruhi perkembangan kekuatan dan kemampuan motorik; (3) kelenjar endokrin, yang mengakibatkan timbulnya pola-pola tingkah laku baru, misalnya di usia remaja berkembang perasaan senang untuk aktif di sebuah kegiatan, dimana sebagian dari anggotanya terdiri dari lawan jenis; dan (4) struktur fisik/tubuh, yang terdiri dari tinggi, berat dan proporsi.. Tugas dan fungsi penting pendidikan PAUD adalah pengembangan yang optimal dan penanaman motorik atau gerak yang benar. Karena pembelajaran di tingkat PAUD adalah pemeriksaan secara dini dan bertahap pada kemampuan gerak dasar yang optimal terhadap usianya dimana kemaksimalan kemampuan untuk mendapat kesenangan melalui gerak, dengan demikian anak akan mendapat kualitas gerak berkelanjutan dari gerak dasar yang benar menuju gerak khusus yang dibutuhkan anak. Hal ini didasarkan pada hasil observasi awal yang dilakukan pada kelompok B di Pos Paud Terpadu Kartini Kota Surabaya, terlihat bahwa semangat siswa kurang dalam mengikuti senam irama terutama dalam gerakannya. Ini bisa di buktikan dengan beberapa siswa yang masih mengikuti kegiatan senam sampai selesai. Sedangkan yang lain masih ada siswa yang belum mau untuk mengikuti kegiatan dan ada juga yang hanya berbaris melihat saja. Hal ini terjadi karena guru dalam pemberian kegiatan senam kurang begitu aktif. Maka dari itu bisa membuat siswa kurang tertarik dan kurang semangat. Hasil pengamatan yang dilakukan oleh peneliti menunjukkan adanya cara dan gaya guru dalam mengajar terkesan monoton sehingga anak cepat menjadi bosan. Guru kurang memaksimalkan untuk pelatihan gerak dasar fisik dan motorik sebagai pembelajaran. Upaya meningkatkan kemampuan motorik kasar pada anak usia dini, dapat dilakukan dengan menggunakan berbagai cara dan berbagai media. Penerapan gerakan senam ceria yang diimplementasikan melalui beberapa pengembangan gerak dasar, di antaranya 1) menggerakkan kepala, tangan atau kaki sesuai dengan irama musik/ ritmik, 2) mengikuti gerakan senam sederhana sesuai irama musik, 3) mengekspresikan diri dalam gerak, dan 4) mengekspresikan diri secara bebas sesuai irama musik, menurut pendapat Sujiono (2007:1.5), pertumbuhan metorik kasar anak dapat berkembang secara optimal karena secara langsung maupun tidak langsung akan mempengaruhi perilaku anak sehari-harinya. Secara langsung pertumbuhan fisik anak menentukan keterampilannya dalam bergerak. Sementara itu secara tidak langsung, pertumbuhan dan perkembangan kemampuan motorik kasar anak mempengaruhi cara anak memandang dirinya sendiri dan orang lain. Berdasarkan hal-hal di atas, peneliti berupaya menemukan solusi pemecahan masalah melalui penelitian tindakan kelas. Dalam hal ini penelitian tindakan kelas perlu dilakukan guna mengetahui kualitas dan tingkat capaian perkembangan kemampuan motorik kasar siswa dengan mengambil "Peningkatan Minat Siswa Terhadap Kegiatan Fisik Motorik Melalui Gerakan Senam Ceria Kelompok B di Pos Paud Terpadu Kartini Kota Surabaya”. 


\section{METODOLOGI}

Peneliti ini menggunakan jenis penelitian PTK (Penelitian Tindakan Kelas). Penelitian Tindakan Kelas (PTK) merupakan proses investigasi terkendali untuk menemukan dan memecahkan masalah pembelajaran dikelas. Akbar dalam Ihsan (2013: 44) mengatakan bahwa Proses pemecahan masalah yang dilakukan dengan cara siklus, bertujuan untuk meningkatkan kualitas pembelajaran serta hasil pembelajaran dikelas tertentu. Subyek penelitian adalah Guru PAUD, dan Obyek penelitiannya adalah siswa kelompok B di Pos Paud Terpadu Kartini Kota Surabaya. Yaitu ada 10 siswa, 5 siswa perempuan dan 5 siswa laki-laki. Dalam melaksanakan penelitian, peneliti melakukan siklus pertama yang terdiri dari proses perencanaan (planning), pelaksanaan (acting), observasi (observing), dan refleksi (reflecting). Pada Kemmis dan Mc Taggart, antara setiap langkah dalam siklus tersebut saling keterkaitan. Munurut Kemmis dan Mc Taggart dalam Arikunto (2006: 97) model alur penelitian itu terdiri dari empat kegiatan pokok yaitu perencanaan pelaksanaan, pengamatan, dan refleksi. Teknik pengumpulan data menggunakan teknik dokumentasi dan observasi. Pada teknik analisis data, data yang di analisis oleh peneliti adalah hasil kegiatan pembelajaran yang berkaitan dengan peningkatan minat siswa dalam kegiatan fisik motorik melalui penerapan gerakan senam ceria. Analisis pembelajaran siswa dilakukan pada setiap pertemuan dalam siklus I dan II. Adapun rumus yang digunakan dalam analisa data dengan teknik diskriptif kuantitatif presentasi menurut Anas Sujiono(1986: 146) sebagai berikut :

$$
P=\frac{F}{N} \times 100 \%
$$

Keterangan :

$P \quad=$ Angka persentase

$F \quad=$ Frekuensi yang sedang dicari

Presentasenya

$N=$ Jumlah Frekwensi

Hal ini berdasarkan pendapat Zainal Aqip (dalam Ihsani 2013), maka penelitian ini dinyatakan berhasil dan termasuk dalam kategori berkembang sesuai harapan jika 75\% dari jumlah siswa mendapat skor 3 atau bintang 3 dan skor 4 atau bintang 4 pada masing-masing indikatornya.

\section{HASIL DAN PEMBAHASAN}

\section{Hasil Observasi Pra Tindakan}

Sebelum melakukan penelitian, peneliti melakukan tindakan observasi terlebih dahulu yang dilaksanakan pada tanggal 4, 5, dan 6 Oktober 2018, bagaimana mengetahui kemampuan motorik kasar yang dimiliki oleh siswa kelompok B di Pos Paud Terpadu Kartini. . Kegiatan Pra Tindakan dilakukan pada tanggal 21 Februari 2019. Dari hasil Pra Tindakan yang dilakukan terhadap siswa di kelas $\mathrm{B}$, mengenai kemampuan motorik kasar pada siswa 
kelompok B di Pos Paud Terpadu Kartini masih kurang optimal. Hal ini bisa dilihat pada tabel berikut.

Tabel 3. Rekapitulasi Data Kegiatan Fisik Motorik Siswa (PraTindakan)

\begin{tabular}{|c|c|c|c|c|c|c|c|c|}
\hline \multirow[b]{2}{*}{ No } & \multirow[b]{2}{*}{ Inisial } & \multicolumn{4}{|c|}{ Instrumen } & \multirow[b]{2}{*}{ Skor } & \multirow[b]{2}{*}{$\begin{array}{l}\text { Rata- } \\
\text { rata }\end{array}$} & \multirow[b]{2}{*}{$\begin{array}{c}\text { Prosentase } \\
(\%)\end{array}$} \\
\hline & & $\begin{array}{c}\text { Mengger } \\
\text { akkan } \\
\text { kepala, } \\
\text { tangan } \\
\text { atau kaki } \\
\text { sesuai } \\
\text { dengan } \\
\text { irama } \\
\text { musik/ } \\
\text { ritmik }\end{array}$ & $\begin{array}{c}\text { Mengiku } \\
\text { ti } \\
\text { gerakan } \\
\text { senam } \\
\text { sederhan } \\
\text { a sesuai } \\
\text { irama } \\
\text { musik }\end{array}$ & $\begin{array}{l}\text { Menge } \\
\text { kspresi } \\
\text { kan diri } \\
\text { dalam } \\
\text { gerak }\end{array}$ & $\begin{array}{c}\begin{array}{c}\text { Mengeks } \\
\text { presikan } \\
\text { diri }\end{array} \\
\text { secara } \\
\text { bebas } \\
\text { sesuai } \\
\text { irama } \\
\text { musik }\end{array}$ & & & \\
\hline 1. & $\mathrm{AI}$ & - & - & - & - & - & - & - \\
\hline 2. & $\mathrm{AL}$ & 2 & 2 & 2 & 1 & 7 & 1,75 & 43,75 \\
\hline 3. & AR & 1 & 1 & 1 & 1 & 4 & 1 & 25 \\
\hline 4. & $\mathrm{CH}$ & 2 & 2 & 2 & 2 & 8 & 2 & 50 \\
\hline 5 . & ER & 2 & 2 & 2 & 2 & 8 & 2 & 50 \\
\hline 6. & FA & - & - & - & - & - & - & - \\
\hline 7. & FAT & 2 & 2 & 2 & 1 & 7 & 1,75 & 43,75 \\
\hline 8. & FI & 2 & 3 & 2 & 2 & 9 & 2,25 & 56,25 \\
\hline 9. & KA & 2 & 2 & 3 & 2 & 9 & 2,25 & 56,25 \\
\hline 10. & QI & 2 & 2 & 2 & 2 & 8 & 2 & 50 \\
\hline \multicolumn{6}{|c|}{ Jumlah } & 60 & 15 & 375 \\
\hline \multicolumn{6}{|c|}{ Rata-rata } & 6 & 1,5 & 37,5 \\
\hline
\end{tabular}

\section{Keterangan :}

Nilai 1 : Belum Berkembang (BB)

Nilai 2 : Mulai Berkembang (MB)

Nilai 3 : Berkembang Sesuai Harapan (BSH)

Nilai 4 : Berkembang Sangat Baik (BSB)

Berdasarkan atas penjabaran tabel di atas, maka peningkatan siswa dalam kegiatan fisik motorik sangat kurang, masih banyak siswa yang belum mau melakukan gerakan berkembang sesuai harapan dan berkembang sangat baik. Dengan demikian dapat diartikan bahwasannya penigkatan siswa dalam kegiatan fisik motorik pada siswa kelompok B di Pos Paud Terpadu Kartini Kota Surabaya belum maksimal berdasarkan kriteria prosentase penyesuaian. Maka dari itu, hal demikian menjadi landasan untuk meningkatkan minat siswa dalam kegiatan fisik motorik melalui penerapan gerakan senam ceria. Atas dasar data diatas, peneliti melanjutkan melakukan kegiatan siklus pertama supaya dapat mengetahui kemampuan siswa dalam mengikuti kegiatan senam ceria.

\section{Siklus I}

Tindakan Siklus I dilaksanakan dalam 3 pertemuan, pertemuan pertama dilaksanakan pada kamis, 14 Maret 2019, pertemuan ke dua dilaksanakan jum'at, 15 Maret 2019 dan pertemuan ke tiga dilaksanakan sabtu, 16 Maret 2019. Selama proses pembelajaran dengan menerapkan media senam ceria, peneliti melakukan pengamatan terhadap pelaksanaan pembelajaran yang 
dilaksanakan oleh guru dan aktivitas siswa selama pembelajaran. Dengan melihat Tindakan Siklus I dapat disimpulkan gambaran mengenai hasil unjuk kerja " Meningkatnya Minat Siswa dalam Kegiatan Fisik Motorik". Adapun hasil dari pertemuan siklus I dapat dilihat pada tabel dibawah ini.

Tabel 5. Rekapitulasi Data Peningkatan Minat Siswa dalam Kegiatan Fisik Motorik pada Siklus I

\begin{tabular}{|c|c|c|c|c|c|c|c|c|}
\hline \multirow[b]{2}{*}{ No } & \multirow[b]{2}{*}{ Inisial } & \multicolumn{4}{|c|}{ Instrumen } & \multirow[b]{2}{*}{ Skor } & \multirow[b]{2}{*}{$\begin{array}{l}\text { Rata- } \\
\text { rata }\end{array}$} & \multirow[b]{2}{*}{$\begin{array}{c}\text { Prosentase } \\
(\%)\end{array}$} \\
\hline & & $\begin{array}{l}\text { Mengger } \\
\text { akkan } \\
\text { kepala, } \\
\text { tangan } \\
\text { atau kaki } \\
\text { sesuai } \\
\text { dengan } \\
\text { irama } \\
\text { musik/ } \\
\text { ritmik }\end{array}$ & $\begin{array}{l}\text { Mengiku } \\
\text { ti } \\
\text { gerakan } \\
\text { senam } \\
\text { sederhan } \\
\text { a sesuai } \\
\text { irama } \\
\text { musik }\end{array}$ & $\begin{array}{c}\text { Menge } \\
\text { kspresi } \\
\text { kan diri } \\
\text { dalam } \\
\text { gerak }\end{array}$ & $\begin{array}{c}\text { Menge } \\
\text { kspresi } \\
\text { kan diri } \\
\text { secara } \\
\text { bebas } \\
\text { sesuai } \\
\text { irama } \\
\text { musik }\end{array}$ & & & \\
\hline 1. & $\mathrm{AI}$ & 2 & 2 & 2 & 1 & 7 & 1,75 & 43,75 \\
\hline 2. & $\mathrm{AL}$ & 2 & 2 & 2 & 1 & 7 & 1,75 & 43,75 \\
\hline 3. & $\mathrm{AR}$ & 1 & 1 & 1 & 1 & 4 & 1 & 25 \\
\hline 4. & $\mathrm{CH}$ & 3 & 3 & 3 & 3 & 12 & 3 & 75 \\
\hline 5. & ER & 3 & 3 & 3 & 2 & 11 & 2,75 & 68,75 \\
\hline 6. & FA & 1 & 2 & 2 & 1 & 6 & 1,5 & 37,5 \\
\hline 7. & FAT & 3 & 3 & 3 & 2 & 11 & 2,75 & 68,75 \\
\hline 8. & FI & 3 & 3 & 3 & 2 & 11 & 2,75 & 68,75 \\
\hline 9. & KA & 3 & 3 & 3 & 3 & 12 & 3 & 75 \\
\hline 10. & QI & 1 & 2 & 2 & 1 & 6 & 1,5 & 37,5 \\
\hline \multicolumn{6}{|c|}{ Jumlah } & 87 & 21,75 & 543,75 \\
\hline \multicolumn{6}{|c|}{ Rata-rata } & 8,7 & 2,175 & 54,375 \\
\hline
\end{tabular}

Dari data yang diambil dari siklus I memperoleh skor nilai rata-rata kelas 8,7 dihitung dari jumlah total nilai dibagi jumlah murid. Sedang nilai prosentase rata-rata kelas dapat dihitung dengan rumus :

$$
P=\frac{f}{n} \times 100 \% \text { yang menunjukkan hasil }
$$

Berdasarkan dari hasil pengamatan serta diskusi peneliti dan guru diatas, ternyata dapat diketahui masih banyak siswa yang belum sesuai harapan dalam melakukan unjuk kerja senam ceria dalam kegiatan "peningkatan minat dalam kegiatan fisik motorik" sehingga perlu dilanjutkan dalam upaya peningkatan minat siswa dalam kegiatan fisik motoriknya. Dari data tersebut diperoleh hal-hal yang menjadi hambatan pada tindakan siklus I, serta upaya perbaikan yang akan dilakukan pada tindakan siklus II di uraikan pada tabel berikut.

Tabel 6. Hambatan dan Upaya Perbaikan untuk Tindakan Siklus II 


\begin{tabular}{|l|l|}
\hline $\begin{array}{l}\text { 1).Pada saat guru mendemonstrasikan } \\
\text { gerakan senam ceria, tidak ada instruktur } \\
\text { pendamping yang mengarahkan siswa dalam } \\
\text { melakukan setiap gerakan senam ceria. }\end{array}$ & $\begin{array}{l}\text { 1). Selain penelitih, guru meminta bantuan } \\
\text { pada guru lain untuk mendampingi dan } \\
\text { membantu siswa pada saat menirukan } \\
\text { gerakan senam ceria. }\end{array}$ \\
\hline $\begin{array}{l}\text { 2). Adanya satu atau dua siswa yang tidak } \\
\text { mengikuti senam sehat ceria, bisa } \\
\text { mempengaruhi kosentrasi siswa yang } \\
\text { mengikuti senam ceria. }\end{array}$ & $\begin{array}{l}\text { 2).Guru pendamping harus memberikan } \\
\text { support dan arahan kepada siswa yang } \\
\text { tidak mengikuti senam ceria, serta siswa } \\
\text { yang mengikuti gerakan senam ceria bisa } \\
\text { lebih berkosentrasi saat melakukan } \\
\text { kegiatan senam ceria. }\end{array}$ \\
\hline $\begin{array}{l}\text { 3). Pemberian contoh yang dilakukan oleh } \\
\text { guru pada saat mendemonstrasikan gerakan } \\
\text { senam ceria kurang berenergik. }\end{array}$ & $\begin{array}{l}\text { 3) Guru dalam mendemonstrasikan } \\
\text { gerakan senam harus memaksimalkan } \\
\text { gerakan, supaya siswa timbul semangat } \\
\text { untuk melakukan gerakan senam ceria. }\end{array}$ \\
\hline
\end{tabular}

Dari hasil refleksi yang dilakukan pada tindakan siklus I, bahwa peningkatan minat siswa dalan kegiatan fisik motorik kelompok B di Pos Paud Terpadu Kartini Kota Surabaya belum mencapai keberhasilan yang ditetapkan.

\section{Siklus II}

Dengan melihat Tindakan Siklus II dapat disimpulkan gambaran mengenai hasil unjuk kerja "Meningkatnya Minat Siswa dalam Kegiatan Fisik Motorik". Adapun hasil dari pertemuan siklus II dapat dilihat pada tabel dibawah ini.

Tabel 8. Rekapitulasi Data Kegiatan Fisik Motorik Siswa (Siklus II)

\begin{tabular}{|c|c|c|c|c|c|c|c|c|}
\hline \multirow[b]{2}{*}{ No } & \multirow[b]{2}{*}{ Inisial } & \multicolumn{4}{|c|}{ Instrumen } & \multirow[b]{2}{*}{ Skor } & \multirow[b]{2}{*}{$\begin{array}{c}\text { Rata- } \\
\text { rata }\end{array}$} & \multirow[b]{2}{*}{$\begin{array}{c}\text { Prosentase } \\
(\%)\end{array}$} \\
\hline & & $\begin{array}{c}\text { Menggerak } \\
\text { kan kepala, } \\
\text { tangan atau } \\
\text { kaki sesuai } \\
\text { dengan } \\
\text { irama } \\
\text { musik/ } \\
\text { ritmik }\end{array}$ & $\begin{array}{l}\text { Mengikuti } \\
\text { gerakan } \\
\text { senam } \\
\text { sederhana } \\
\text { sesuai } \\
\text { irama } \\
\text { musik }\end{array}$ & $\begin{array}{c}\text { Menge } \\
\text { kspresi } \\
\text { kan diri } \\
\text { dalam } \\
\text { gerak }\end{array}$ & $\begin{array}{c}\text { Mengeks } \\
\text { presikan } \\
\text { diri } \\
\text { secara } \\
\text { bebas } \\
\text { sesuai } \\
\text { irama } \\
\text { musik }\end{array}$ & & & \\
\hline 1. & $\mathrm{AI}$ & 3 & 4 & 3 & 3 & 13 & 3,25 & 81,25 \\
\hline 2. & $\mathrm{AL}$ & 3 & 4 & 4 & 3 & 14 & 3,5 & 87,5 \\
\hline 3. & AR & 2 & 4 & 3 & 3 & 12 & 3 & 75 \\
\hline 4. & $\mathrm{CH}$ & 3 & 4 & 4 & 4 & 15 & 3,75 & 93,75 \\
\hline 5. & ER & 3 & 4 & 4 & 3 & 14 & 3,5 & 87,5 \\
\hline 6. & FA & 2 & 4 & 3 & 3 & 12 & 3 & 75 \\
\hline 7. & FAT & 3 & 4 & 3 & 4 & 14 & 3,5 & 87,5 \\
\hline 8. & FI & 3 & 4 & 4 & 4 & 15 & 3,75 & 93,75 \\
\hline 9. & KA & 3 & 4 & 4 & 4 & 15 & 3,75 & 93,75 \\
\hline 10. & QI & 2 & 4 & 3 & 3 & 12 & 3 & 75 \\
\hline \multicolumn{6}{|c|}{ Jumlah } & 136 & 34 & 850 \\
\hline \multicolumn{6}{|c|}{ Rata-rata } & 13,6 & 3,4 & 85 \\
\hline
\end{tabular}

Dari data yang diambil dari Siklus II memperoleh skor nilai rata-rata kelas 13,6 dihitung dari jumlah total nilai dibagi jumlah murid. Sedang nilai prosentase rata-rata kelas dapat dihitung dengan rumus: 


$$
P=\underset{n}{f} \times 100 \% \text { yang menunjukkan hasil } \frac{13,6}{16} \times 100 \%=85
$$

Dari hasil evaluasi keseluruhan kegiatan senam ceria mengalami perkembangan yang signifikan. Semua siswa begitu antusias dalam melaksanakan senam ceria. Siswa mengikuti kegiatan senam ceria dari awal sampai selesai, walaupun masih terdapat siswa yang sebentar berhenti, setelah itu siswa melanjutkan gerakan kembali. Semua siswa terlihat semangat dan merasa senang sekali.

Berdasarkan hasil observasi Siklus I, Siklus II yang sudah dilakukan oleh peneliti, maka perubahan peningkatan minat siswa yang terlihat selama penelitian dapat dilihat pada tabel observasi berikut ini :

Tabel 9. Rekapitulasi Perbandingan Skor

\begin{tabular}{|c|l|c|c|c|c|c|c|}
\hline \multirow{2}{*}{ No } & \multirow{2}{*}{ Nama } & \multicolumn{2}{|l|}{ Pra Tindakan } & \multicolumn{2}{c|}{ Siklus I } & \multicolumn{2}{c|}{ Siklus II } \\
\cline { 3 - 8 } & & Skor & $\%$ & Skor & $\%$ & Skor & $\%$ \\
\hline 1 & AI & - & -- & 7 & 43,75 & 13 & 81,25 \\
\hline 2 & AL & 7 & 43,75 & 7 & 43,75 & 14 & 87,5 \\
\hline 3 & AR & 4 & 25 & 4 & 25 & 12 & 75 \\
\hline 4 & CH & 8 & 50 & 12 & 75 & 15 & 93,75 \\
\hline 5 & ER & 8 & 50 & 11 & 68,75 & 14 & 87,5 \\
\hline 6 & FA & - & - & 6 & 37,5 & 12 & 75 \\
\hline 7 & FAT & 7 & 43,75 & 11 & 68,75 & 14 & 87,5 \\
\hline 8 & FI & 9 & 56,25 & 11 & 68,75 & 15 & 93,75 \\
\hline 9 & KA & 9 & 56,25 & 12 & 75 & 15 & 93,75 \\
\hline 10 & QI & 8 & 50 & 6 & 37,5 & 12 & 75 \\
\hline Jumlah & & 60 & 375 & 87 & 543,75 & 136 & 850 \\
\hline Rata-rata & & 6 & 37,5 & 8,7 & 54,375 & 13,6 & 85 \\
\hline
\end{tabular}

Berdasarkan tabel tersebut diatas bisa dilihat peningkatan minat siswa dalam kegiatan fisik motorik kelompok B di Pos Paud Terpadu Kartini dapat dikatakan baik, karena rata-rata siswa mengalami penigkatan. Hal ini dibuktikan dengan adanya hasil obsevasi prosentase setiap siswa pada siklus II mencapai $75 \%$ sampai dengan $93,75 \%$, dan sudah bisa memenuhi target yang diharapkan yaitu $70 \%$. 


\section{PENUTUP}

\section{Kesimpulan}

Berdasarkan hasil penelitian dan pembahasan bisa disimpulkan bahwa (1) dari 10 siswa yang mengikuti gerakan-gerakan yang dipandu guru, ternyata tidak semua mengikuti gerakan tersebut karena kurang adanya variasi gerakan atau musik yang mengiringi.

(2) pada tindakan siklus I dan siklus II telah diketahui ada peningkatan yaitu dari $54,375 \%$ menjadi $85 \%$ dari rata-rata jumlah siswa sehingga bisa masuk kategori BSH (Berkembang Sesuai Harapan). Dari hasil tersebut, maka bisa dikatakan bahwa hipotesis tindakan yaitu senam ceria dapat meningkatkan minat siswa dalam kegiatan fisik motorik kelompok B di Pos Paud Terpadu Kartini Kota Surabaya bisa dibuktikan. (2) penerapan gerakan senam ceria pada siswa pada kelompok B Pos Paud Terpadu Kartini Kota Surabaya dilakukan secara continue. Maksimal satu minggu tiga kali dan minimal satu minggu dua kali. Hal ini buktikan dengan kegiatan senam ceria yang sudah terlaksana selama penelitian berlangsung

\section{DAFTAR PUSTAKA}

Ihsan. (2013). Upaya Meningkatkan Motorik Kasar Melalui Kegiatan Senam Irama Pada Kelompok A TK Aisyiyah Bustanul Athfal Koripan Pocosari Srandakan Bantul Tahun Pelajaran 2012/2013. Skripsi. Universitas Negeri Yogyakarta, tersedia pada lamanhttps ://eprins. Uny.Ac.id/15437/Fitri\%20Nurul\%20Ihsani\%20BARU.pdf (diunduh 25Januari 2019).

Arikunto, (2006). Prosedur Penelitian. Jakarta: PT RINEKA CIPTA

Aqip, Zaenal. (2007). Membangun Profesionalisme Guru dan Pengawas Sekolah. Bandung: CV Yrama Widya.

Sujiono, Anas. 1986. Teknik Evaluasi Pendidikan. Jakarta: Rineka Cipta.

Hurlock, E.B. (1956). Perkembangan Anak. Jakarta: Erlangga

Sujiono, (2007). Pengertian Bermain Anak Usia Dini. PT Indek, Jakarta. 


\title{
THE IMPROVEMENT OF ENGLISH WRITING AND STUDENTS' MOTIVATION THROUGH BRAINSTORMING
}

\author{
Varia Virdania Virdaus \\ Email: varia.virdania@gmail.com \\ Narotama University Surabaya
}

\begin{abstract}
Brainstorming activity is a main factor that can give effect on students' writing motivation. Teaching English writing by using brainstorming strategy is really important especially to increase students' motivation. This research is aimed at investigating the effect of brainstorming and its relation to students' motivation in English writing for the second semester students of Management Major of STIE Perbanas Surabaya, numbering 25 students in academic year 2018-2019. Classroom Action Research (CAR) method was applied in this research. Researcher could investigate and analyze brainstorming process by using this method. Applying brainstorming strategy, the participants (students) were more motivated in terms of writing, which at this time was English writing with a particular topic. Result of this study revealed that brainstorming strategy could improve students' English Writing skill and their motivation in writing. They could produce good and effective words, and also interesting answers. Based on the fact, brainstorming strategy is suggested for teaching English Writing. Students' motivation in writing much higher than without brainstorming strategy.
\end{abstract}

Key Words: Brainstorming, Motivation, English Writing

\begin{abstract}
ABSTRAK
Kegiatan brainstorming adalah faktor utama yang dapat memberikan efek pada motivasi menulis siswa. Mengajar menulis bahasa Inggris dengan menggunakan strategi curah pendapat sangat penting terutama untuk meningkatkan motivasi siswa. Penelitian ini bertujuan untuk menyelidiki pengaruh brainstorming dan hubungannya dengan motivasi siswa dalam menulis bahasa Inggris untuk mahasiswa semester kedua Jurusan Manajemen STIE Perbanas Surabaya, yang berjumlah 25 siswa pada tahun akademik 2018-2019. Metode Penelitian Tindakan Kelas (PTK) diterapkan dalam penelitian ini. Peneliti dapat menyelidiki dan menganalisis proses brainstorming dengan menggunakan metode ini. Menerapkan strategi curah pendapat, para peserta (siswa) lebih termotivasi dalam hal penulisan, yang saat ini adalah penulisan bahasa Inggris dengan topik tertentu. Hasil penelitian ini mengungkapkan bahwa strategi brainstorming dapat meningkatkan keterampilan menulis bahasa Inggris siswa dan motivasi mereka dalam menulis. Mereka dapat menghasilkan katakata yang baik dan efektif, dan juga jawaban yang menarik. Berdasarkan fakta, strategi curah pendapat disarankan untuk mengajar Menulis Bahasa Inggris. Motivasi siswa dalam menulis jauh lebih tinggi daripada tanpa strategi curah pendapat.
\end{abstract}

Kata Kunci: Brainstorming, Motivasi, Penulisan Bahasa Inggris 


\section{INTRODUCTION}

Writing is very important in our life. By writing we are able to share our ideas and thoughts. Besides listening and speaking, writing also has an important role in effective communication. Nowadays, communication is more often done in writing than orally, as we find in social media. In learning English, writing is one step to speak English more organized and easy. However, learning to write in English is still not easy, especially for non-English Department students.

Writing also requires motivation, if students are motivated to write then the writing that they produce will be better and full of good ideas, and of course the content of their writing more interesting. Based on Lathif, Masyhudi (2017), motivation becomes one of the determinants of one's success in second and foreign language learning. Motivation is an area in which teachers can play a role in influencing and giving positive feedback to students from time to time.

Students who have high learning motivation, especially in learning English, then their achievement in learning English will also be good. Conversely, if less motivation in learning English, then student achievement will also decrease. Student learning motivation often occurs up and down, one of them because of their boring learning methods. Brainstorming has now become one way to improve students' learning motivation to be more creative and not boring. Brainstorming activity is a main factor that can give effect on students' writing motivation. Brainstorming and writing motivation are two main things in second language learning.

In fact, teaching English writing by using brainstorming method is really important especially to increase students' motivation. But somehow, teachers or lecturers use different method in giving brainstorming to students without examining how it could influence the students' motivation in writing. The same thing is also revealed by Mohammad, Mohammad and Ali Ahmed (2013), that EFL teacher for English usually uses different method for brainstorming. Literally, the use of brainstorming helps the student to think creatively, discuss, and solve the problems.

A good method can give powerful effect in motivating students to start writing English. Problems that they usually faced in writing English are varied, as they lack of vocabularies, find some difficulties in building sentences, or perhaps lack of ideas about what 
to write. By using Brainstorming, it is hoped that students' motivation in writing English could increase.

Based on the background above, researcher formulates the research problems as follows: 1) How can brainstorming give effects to students' motivation in writing English? 2) How is the process of implementation of brainstorming that can motivate students in writing English? According to the statement of the problems, the researcher is aimed to find out: 1) Describing how brainstorming give effects to students' motivation in writing English, 2) Describing the process of implementation of brainstorming that can motivate students in writing English. This research is aimed at investigating the effect of brainstorming and its relation to students' motivation in English writing for the second semester students of Management Major of STIE Perbanas Surabaya, numbering 25 students in academic year 2018-2019.

\section{LITERATURE REVIEW}

\section{Writing}

Writing has been with us for several hundred years, and it is very important for our lives. Millions of people rely on writing although not everyone can read and write. Writing becomes one of the important factors of communication in society. Based on Coulmas, writing has six meaning that can be distinguished as follows: (1) A system of recording language; (2) The activity of putting such a system to use; (3) The result of such activity, a text; (4) The particular form of such a result, a script style such as block letter writing; (5) Artistic composition; (6) A professional occupation.

According to William Hazzlit, the nineteenth-century novelist, "The more a man writes, the more he can write." This quote means, students will not make much progress in writing if they are not given opportunities to write, develop, and explore their ability. Graham \& Perin (2007b) also stated that students should spend at least one hour or even more each day in the process of writing (planning, revising, authoring, or publishing text) in order to improve their skill. There are multiple purposes for students to learn to write: for communicating with others (by business letter, by note, etc); Learning content material; Informing others; Responding to literature; and demonstrating knowledge.

\section{Motivation}


Motivation is important encouragement of human behavior that guarantees higher performance in any field. Psychologist said that human motivation as being 'moved to do something' that satisfies the fundamental need for 'competence, autonomy and relatedness' (Ryan and Deci, 2000:54; 57). A 'moving idea or fact or judgment' might trigger personal interest and consequently intrinsic motivation (Walker 1952: 6) in Kirchhoff, Leonie (2016).

Motivation intention depends on family relationship with second language learners, personal experience, impact of the social environment, etc (Noels, 2001; Dornyei, 2005). In second and foreign Language learning, motivation becomes the primary factor in determining one's success. This is in accordance with Dornyei (1994), motivation has become one of the main factor in students' achievement in learning second and foreign language. Based on Oxford \& Shearin (1996), students who have no motivation in learning second and foreign language, they cannot develop their ability.

\section{Brainstorming}

Arivananthan (2015) stated that Brainstorming is meant to stimulate the brain into thinking about issues in a new way. It encourages people to arrest conventional, logical thinking and embrace spontaneity, originality, and imagination. Participants in a Brainstorming session express their thoughts or ideas quickly and spontaneously. The goal is to collect as many ideas as possible in a short time. So that the greater the number of ideas generated, the greater the chance of producing English essay and effective solution.

Based on Eikenberry (2007) statement, brainstorming strategy conduct seven spurring questions, as follows:

1. How would $X$ do it (or solve this problem)? In the place of "X" you can place another department, another company, your Mother, a 10 year old, Benjamin Franklin, a character from a book or movie, anybody.

2. What would we do if the problem were twice as big (or half as big)? Looking at extremes is another way to spur new ideas.

3. How would we solve the opposite problem? By reversing the problem and making that list, we are often able then to turn those answers back around into new alternatives.

4. What does this problem remind us of? If we can find other situations in our experience to connect to this situation, new ideas will come out. 
5. How is this problem like $X$ ? In this case the " $X "$ is any word or phrase. By forcing the connections to the random word, new ideas will burst forth. To get your word you can open a dictionary to a random page and find a random word or you can use a random word list that you have previously prepared.

6. How can we do A and B? Perhaps the best alternative isn't with one idea.

7. How can we combine some of the ideas we have to find new and different ideas?

These questions can be asked by Teachers/ Lecturer or Leader, to help Students spur their thoughts. Each of the questions will create a new perspective and generates new connections in their minds.

\section{METHODOLOGY}

This research used Classroom Action Research (CAR) as the design and applying a spiral model as suggested by Kemmis and Taggart (1988) consisting of planning, acting, observing, and reflecting. It was used because of some reasons: 1) This research was done in natural ways; 2) This research concerned to improve motivation in English writing.

The participants of this study were 25 Management Major Students of STIE Perbanas Surabaya, at the academic year 2018/2019. They were at the second semester when this study was conducted. The second semester students were chosen because they had English subject at this semester. The researcher could easily meet the students once a week, so that it was a good time for collecting data to conduct the research.

The procedure of collecting data was: 1) Quantitative data were taken from writing test given by the researcher during the process of teaching; 2) Qualitative data were taken by the researcher by writing the lecturer's and students' activities and creativities during the process of teaching and learning English. The participants completed all the process by giving ideas and answering the $\mathrm{W} \& \mathrm{H}$ questions through writing.

After the data have been collected, they were analyzed as the follow: for quantitative data, the researcher applied the mean formula for the assessment, for qualitative data the researcher collecting the raw data, reducing the raw data, and analyze the data. As stated in Mohammad and Ali (2013), the analysis of the result was based on lecturer's observation during the process of brainstorming and students' reflections on the process.

\section{RESULT AND DISCUSSION}

\section{Cycle 1}


This research investigated the improvement of English Writing and students' motivation through brainstorming from Management Major students of STIE Perbanas Surabaya in the second semester 2018/2019 numbering 25.

Brainstorming could motivate students to discuss, think creatively, solve the problem, and finish the task given individually or in a team. By brainstorming, students compiled some ideas and examples for a given topic and it also helped them to develop their topic. So that, they had motivation to learn and write in English.

Motivation could indicate how students learn effectively. When motivation is high, students could learn effectively, but when motivation is low, students could take longer time to study or to learn something especially the writing skill (Prakash, 2007). If brainstorming and motivation were collaborated together as tools for English writing learning, the result for students' skill and comprehension toward English writing must be good. It was expected to occur to the Management major students of STIE Perbanas Surabaya where they had motivation in writing English.

\section{a. Meeting 1}

The researcher is the main source of data, because she was not only as a researcher, but also as a lecturer. At the beginning of the class, the lecturer prepared the class for English subjects, included greeting and checking students' presence. Time allocation was $2 \times 45$ minutes (1 meeting). Students were given writing material, after that they wrote free topic paragraphs. The researcher identified the answers from the students. Most of them wrote paragraphs irregularly and out of topic.

\section{b. Meeting 2}

Lecturer (researcher) prepared the class for the English Subject. The lecturer gave the students writing test by giving them certain topic "Indonesian Economic Condition". This topic was very good to be given because it was appropriate with their major. First step, students wrote paragraphs about the topic given and then they submitted to the lecturer directly after finished. Next, the lecturer made sure that the students had focused on the materials (the topic), so that, she continued to give them brainstorming sheet.

Researcher (lecturer) applied one of brainstorming strategy that is used by Eikenberry (2007). Researcher used this strategy because it is easier to be applied and delivered to the students than other brainstorming strategies. There are seven questions (brainstorming sheet) to conduct this brainstorming strategy, as follows:

\section{How would "students" do it (or solve this problem)?}


"Students were asked about the solution of the problem based on the topic given"

2. What would we do if the problem were twice as big (or half as big)?

"Make students try to think another way to spur new ideas"

3. How would we solve the opposite problem?

"By reversing the problem and making that list, Students were often able then to turn those answers back around into new alternatives"

4. What does this problem remind us of?

"Students were asked to find other situations in their experience to connect to this situation, and then new ideas would come out"

5. How is this problem like $X$ ? (In this case the " $\mathrm{X}$ " is any word or phrase).

"By forcing the connections to the random word, new ideas will burst forth. To get the students' words they opened a dictionary to a random page and found a random word or they used a random word list that they have previously prepared."

6. How can we do A and B?

"Perhaps the best alternative isn't with one idea, Students had to think more than one thing"

7. How can we combine some of the ideas, we have to find new and different ideas?

"Students had to think how to combine some of their ideas to be good statements"

Each of the questions created a new perspective and generates new connections in their minds. Each student was given a sheet of brainstorming strategy (consist of 7 questions). This procedure was aimed to identify English Writing skill for students. The answer sheets were submitted to the lecturer, then the lecturer evaluated all the answers (step 1 and step 2) in meeting 2 and wrote the mark in writing rubric.

\section{Observing}

The researcher tried to identify the problem in cycle 1 . There were some problems during the writing learning process by using brainstorming strategy. In the beginning, students did not understand when teacher applied brainstorming strategy to their writing, because it was the first time for them using this strategy. After meeting 2, students began to understand the brainstorming strategy. Based on students' writing score, there were 9 students or $36 \%$ who got $<75 ; 5$ students or $20 \%$ who got score between $76-80 ; 11$ students or $44 \%$ who got score between 81-90; and no students got the score between 91-100. The result from cycle 1 was not satisfying because it was still out of the target. There were 9 students $(36 \%)$ who got low scores. 


\section{Reflection}

From the result of the observation, students seemed still confused with the brainstorming strategy. They did not know about the process and they did not understand how to build sentences using the brainstorming strategy. The result of writing test did not match the criteria of mastery learning that is $75 \%$ individually and $85 \%$ classically. Based on the scores of writing test, there were still many students got low scores i.e. 36\%. From the result in cycle 1 , the researcher conducted cycle 2 with some revisions on the strategy of applying brainstorming.

\section{Cycle 2}

\section{a. Meeting 1}

Lecturer prepared English Writing class as usual, after that Lecturer applied Effective Brainstorming strategy for the first meeting in cycle 2. First of all, she explained the rules of this strategy. Lecturer divided the class into 5 (five) groups consisting 5 (five) students each to conduct effective brainstorming. Lecturer defined the idea to be brainstormed then let the leader of each groups to control. In this meeting, every students of each groups was allowed to contribute. All ideas were evaluated until all ideas were gathered.

The brainstorming was started, the leader selected the member of the group to share their answer. In this situation, everyone did not need to evaluate or criticize the answers until the process of brainstorming was completed. After the process was finished, the answers/ideas were evaluated and were ranked. The results of the evaluation of all the answers were selected. Only the similar concepts were grouped together. After the students got the list down, they discussed the remaining responses as a group. Lecturer guided them to pass all the process. The quantity rather than the quality of ideas was the goal, that was okay for them to think out of the box.

\section{b. Meeting 2}

This meeting was planned using the same brainstorming method as in meeting 1 (cycle 2). Lecturer gave explanation again to the students about this effective brainstorming. The class was divided into 5 groups consisting 5 students each. All the steps in meeting 1 (cycle 2) were repeated in this meeting. Students did not get any difficulties to follow this strategy because they had adapted with the technique. After 15 minutes explanation, the class started the effective brainstorming, and the lecturer started to evaluate. All the answers from students were submitted to the lecturer and they were given scores for their writing.

\section{Observation}


The brainstorming strategy was applied to this class, there was only one problem when using this strategy, few students did not focused to the lecturer, so that few of them did not understand. The students' writing scores were as follows: 4 students or $16 \%$ who got < 75 ; 6 students or $24 \%$ who got scores between $76-80 ; 11$ students or $44 \%$ who got scores between 81-90; and 4 students or 16\% got the scores between 91-100. The data showed only 4 students (16\%) got the low scores. It could be proven that Brainstorming Strategy could improve Writing skill of Students on English subject, and they also had higher motivation in writing.

\section{Reflection}

From the result of the observation in cycle 2, students' scores increase than in cycle 1. The data showed the mean score for cycle 1 was $64 \%$, and for cycle 2 was $84 \%$. Based on the observation and investigation of researcher (Lecturer), it was found that students who were given brainstorming strategy could produce many effective words, good ideas, good problem solving, and interesting answers. They did not even expect to be able to make interesting paragraphs with good words.

But instead, before they were given brainstorming strategy, the words they produced were less interesting, less good ideas, and seem monotonous. Teaching and learning process by using brainstorming strategy was stopped in cycle 2, because the brainstorming strategy had delivered effective and interesting technique for improving students' writing skill, in this case was English writing skill of economic students of STIE Perbanas Surabaya.

\section{CONCLUSION}

By using brainstorming strategy, the participants (students) were more motivated in terms of writing, which at this time was English writing with a particular topic. Questions on the brainstorming sheet that have been arranged in such a way make it easier for students to generate ideas with interesting words, and of course, this could encourage students' motivation especially in English writing. If every writing lesson is given brainstorming, then the students will not easily get bored and they will love the lesson.

The analysis of the data was based on Lecturer's observation and investigation during the process of brainstorming, and also students' activity and work on the process. In cycle 1, there were 9 students or $36 \%$ who got $<75$; 5 students or $20 \%$ who got score between $76-80$; 11 students or $44 \%$ who got score between 81-90; and no students got the score between 91100. The result from cycle 1 was not satisfying because it was still out of the target. There 
were 9 students (36\%) who got low scores. So, the researcher should continue to cycle 2 with some improvements in brainstorming strategy. In cycle 2,4 students or $16 \%$ who got $<75 ; 6$ students or $24 \%$ who got scores between $76-80 ; 11$ students or $44 \%$ who got scores between 81-90; and 4 students or $16 \%$ got the scores between 91-100. In conclusion, brainstorming strategy could improve students' English Writing skill and their motivation in writing. They could produce good and effective words, and also interesting answers. Based on the fact, brainstorming strategy is suggested for teaching English Writing. By this strategy, students' motivation in writing much higher than without brainstorming strategy.

\section{REFERENCES}

Arivananthan, Meena. (2015). Brainstorming: Free-flowing creativity for problem-solving. USA: UNICEF. Online for free download at $h t t p: / / w w w$. unicef.org/knowledgeexchangel

Coulmas. Florian. Writing systems: An introduction to their linguistic analysis. Excerpt. Cambridge: Cambridge University Press. Retrieved from http://www.cambridge.org/0521782171, on May 4, 2017.

Dornyei, Z. (1994). Motivation and motivating in the foreign language classroom. The Modern Language Journal, 78 (3), 273- 284.

Dörnyei, Z. (2005). The psychology of the language learner: Individual differences in second

Dörnyei, Z. and Csizér, K. (2005). The effects of intercultural contact and tourism on language attitudes and language learning motivation. Journal of Language and Social Psychology, 24(4), 327-357.

Elkenberry, K. (2007). Brainstorming startegy: Seven questions that spur better solutions. Retrieved from http://www.sideroad.com/Meetings/brainstorming-startegy.html, on June 1, 2017

Ellis, R. (1994). The study of second language acquisition. Oxford: Oxford University Press.

Graham, S., \& Perin, D. (2007b). What we know, what we still need to know: Teaching adolescents to write. Scientific Studies in Reading,11, 313-336.

Journal of Academic Writing Vol. 6 No 1 Autumn 2016, pages 31-40, retrieved from http://dx.doi.org/10.18552/joaw.v6i1.282

Kirchhoff, Leonie. (2016). Motivation in the Writing Centre: A Peer Tutor's Experience. language acquisition. Mahwah, NJ: Lawrence Erlbaum Associates. 
Lathif, Masyhudi. (2017). Investigating Non-English Department Students' Motivation in EFL Writing. IJIET, e-ISSN 2548-8430, p-ISSN 2548-8422, Vol. 1, No. 1, January 2017.

Moelong, Lexy J. (1988). Metodologi Penelitian Kualitatif. Bandung: Remaja Rosdakarya.

Mohammad, Mohammad Fawzi M. and Ali Ahmed Hussein. (2013). Enhancing Students' Motivation to Write Essays through Brainstorming: A Comparative Study.

International Journal of Humanities and Social Science, Vol. 3, No. 9, May 2013.

Noels, K.A. (2001). New orientations in language learning motivation: Towards model of intrinsic,extrinsic, and integrative orientations and motivation.

Prakash,P. (2007). Psychological Foundation of Education. New Delhi: Kanishka Publishers.

Ryan, R. M. and Deci, E.L. (2000) 'Intrinsic and Extrinsic Motivations: Classic Definitions and New Directions' Contemporary Educational Psychology 25(1), 54-67.

Virdaus, Varia Virdania. (2016). ENHANCING LISTENING ABILITY THROUGH TPT BY USING ADOBE AUDITION 1.5. Cakrawala Pendidikan, 18 (1). pp. 36-46. ISSN 1410-9883, retrieved from http://digilib.stkippgri-blitar.ac.id/463/ on April 28, 2017.

Walker, A. L. (1952) 'Motivation'. College Composition and Communication 3(3), 3.

Z. Dörnyei \& R.Oxford, R.L. \& Shearin, J. (1996). Language learning motivation in a new key. In Oxford, R.L. (Ed.). Language Learning Motivation: Pathways to the New Century. Honolulu: University of Hawaii Press. 121-44. 


\title{
IMPLEMENTASI NILAI KEJUJURAN PADA ANAK USIA DINI MELALUI MEDIA ULAR TANGGA
}

\author{
Endah Hendarwati ${ }^{1}$, Wahono ${ }^{2}$, Aris Setiawan ${ }^{3}$ \\ ${ }^{1,2,3}$ Program Studi PG PAUD, Fakultas Keguruan dan Ilmu Pendidikan \\ ${ }^{2}$ wahono@fkip.um-surabaya.ac.id
}

\begin{abstract}
ABSTRAK
Penelitian ini bertujuan untuk mendeskripsikan perkembangan kejujuran anak melalui media ular tangga. Penelitian ini dilakukan pada PAUD Cahaya Jembatan Merah Suarabaya. Metode yang digunakan pada penelitian ini adalah penelitian kualitatif. Subjek pada penelitian ini adalah anak PAUD Cahaya jemabaran Merah Surabaya, yang terdiri dari 9 anak. Analisis data yang digunakan pada penelitian ini adalah analisis data kualitatif deskriptif. Teknik pengumpulan data dengan lembar observasi, wawancara, dan dokumentasi. Dari hasil penelitian diketahui bahwa dari kegiatan pembelajaran dengan menggunakan media ular tangga, anak mampu merawat dan menjaga benda milik bersama, Anak terbiasa berkata jujur, mau mengakui kesalahan, dan mau minta maaf bila salah, dan memaafkan teman yang berbuat salah. Sehingga dapat disimpulkan bahwa implementasi nilai kejujuran melalui media ular tangga sudah sesuai dengan teori dan praktik di lapangan.
\end{abstract}

Kata kunci: Kejujuran, Media Ular Tangga

\begin{abstract}
This study aims to describe the development of children's honesty through the media ular tangga. This research was conducted on PAUD Cahaya Jembatan Merah Surabaya. The method used in this research is qualitative research. Subjects in this study are children PAUD Cahaya Jembatan Merah Surabaya, which consists of 9 children. Data analysis in this research used descriptive qualitative data analysis. Data collection techniques with observation sheets, interviews, and documentation. From the results of research known that from learning activities by using media ular tangga, Children are able to care and keep things together, Children are accustomed to tell the truth, want to admit mistakes, and want to apologize if wrong, and forgive friends who do wrong. So it can be concluded that the implementation of honesty through the media ular tangga is in accordance with the theory and practice in the field.
\end{abstract}

Keywords: Honesty, Media Ular Tangga 


\section{PENDAHULUAN}

Pada era globalisasi ini bayak elemen masyarakat mengkritik pendidikan Indonesia, pendidikan di Indonesia bisa dikatakan belum berhasil membangun karakter generasi bangsa. Para ahli mengidentifikasi pendidikan di Indonesia gagal karena banyak lulusan sekolah mulai dari pendidikan dasar yaitu SD hingga perguruan tinggi, dari sarjana sampai gelar profesor yang memiliki pikiran yang cerdas tetapi memiliki karakter moral dan kultural yang lemah, tidak bermoral dan tidak jujur. Karakter jujur merupakan harapan dan karakter yang harus di tanamkan pada masyarkat bangsa kita . Hal ini dengan alasan karena nilai kejujuran merupakan yang paling utama dan mendasar dalam kehidupan bermasyarakat, dengan karakter tersebut kita dapat membedakan manusia dari makhluk lain. Oleh karena itu penanaman nilai-nilai kejujuran ditanamkan kepada anak sejak usia dini dengan berbagai metode pembelajaran.

Anak usia dini adalah anak yang berada pada rentan usia 0-6 tahun (UndangUndang Sisdiknas tahun 2003). Pada masa ini seorang anak akan tumbuh dan berkembang sangat pesat, orang tua tidak bisa menggantikannya pada masa- masa yang mendatang. Anak usia dini cepat sekali berkembang di semua aspek pengembangan termasuk aspek moral yang didalamnya mencakup nilai kejujuran. Orang tua dan guru mempunyai kewajiban harus mendidik anak berusia 5-6 tahun agar memiliki perilaku yang baik, dan menjadikannya anak yang berkarakter kuat dan tangguh, nilai karakter yang perlu ditanamkan berkaitan dengan pendidikan karakter nilai kejujuran. Anak sejak usia dini harus ditanamkan jujur (tidak berbohong), mengenal mana yang benar dan mana yang salah, mengenal mana yang baik dan mana yang buruk dan mengenal mana yang diperintah dan mana yang dilarang (Hidayatullah, 2010: 32).

Kejujuran merupakan salah satu hal penting yang digunakan dalam membina hubungan dengan diri sendiri dan orang lain. Menurut Hidayatullah (2010: 33) kejujuran merupakan bagian dari nilai karakter yang harus ditanamkan pada anak sedini mungkin karena nilai kejujuran merupakan nilai kunci dalam kehidupan. Kita dapat membangun landasan yang kokoh apabila pendidikan nilai kejujuran dapat dilakukan 
secara efektif .

Kejujuran merupakan hal yang penting dalam kehidupan manusia, tetapi dalam pelaksanaannya nilai kejujuran merupakan suatu yang sulit dilakukan, seseorang selalu mudah tergoda untuk melakukan kebohongan dan kecurangan disebabkan ingin mendapatkan sesuatu lewat jalan pintas. Kejujuran merupakan sebuah sifat, sikap atau kebiasaan, sehingga kejujuran tidak bisa dibentuk secara instant, tapi harus melalui proses pembiasaan diri dalam waktu yang lama. Penanaman nilai kejujuran dapat dilakukan melalui pendidikan formal di sekolah, yaitu mulai dari Pendidikan Anak Usia Dini. Langkah dalam membangun nilai kejujuran pada anak usia dini dapat dilakukan dengan terlebih dahulu harus dikenalkan konsep atau pemahaman kepada anak usia dini tentang nilai kejujuran. Penanaman nilai- nilai kejujuran pada anak usia dini dapat dilakukan dengan dua pendekatan yaitu pendekatan kognitif dan pendekatan belajar sosial. Pendekatan kognitif digunakan untuk menumbuhkembangkan pengetahuan dan kesadaran anak terhadap pentingnya bersikap jujur Pendekatan belajar sosial yang dilakukan lewat percontohan dan penguatan digunakan untuk membiasakan anak melakukan perbuatan jujur lewat peniruan dan pembiasaan. Kedua pendekatan ini sebaiknya dipahami dan digunakan para orang tua, guru, dan para orang dewasa lainnya.

Orang tua dalam membentuk karakter anak agar anak menjadi orang jujur salah satu cara dengan berperilaku jujur kepada anak usia dini. Jika kita sering berbohong, maka anak dengan sendirinya akan mengartikan bahwa berperilaku tidak jujur merupakan hal yang wajar dan dibenarkan (Isna, 2012: 25). Penanaman nilai kejujuran sejak usia dini juga merupakan salah satu cara untuk menanggulangi tindak pidana korupsi. Anak usia dini berada dalam masa keemasan atau golden age, Anak usia dini yang masih berada dalam masa keemasan ini dapat berkembang secara maksimal dalam semua aspek perkembangannya diantaranya aspek perkembangan moral yang di dalamnya mencakup pendidikan karakter nilai-nilai kejujuran. Proses penanaman nilai kejujuran pada anak dapat dilakukan dengan berbagai cara seperti transfer pengetahuan dan pemahaman, serta keteladanan.

Menurut Suyanto (2010) dalam hasil penelitiannya menunjukkan bahwa sekitar $50 \%$ variabilitas kecerdasan sudah terjadi saat anak berusia 4 tahun. Peningkatan $30 \%$ berikutnya terjadi pada usia 8 tahun, dan 20 
\% sisanya pada pertengahan atau akhir dasawarsa kedua. Oleh karena itu masa usia dini merupakan masa yang paling baik untuk menanamkan Karakter nilai kejujuran. Penanaman karakter sejak usia dini sangat berguna untuk membentuk generasi muda yang berkualitas ke depannya. Salah satu cara menanamkan nilai kejujuran pada anak usia dini dengan menggunakan permainan ular tangga. Permainan ular tangga dapat menanamkan nilai kejujuran pada anak lebih efektif, karena dengan bermain ular tangga anak akan lebih tertarik dan dapat mengingat lebih lama.

\section{Pengertian Kejujuran.}

Menurut Ibung (2009:69) kejujuran merupakan suatu kemampuan untuk mengakui perasaan atau pemikiran atau juga tindakan seseoarang kepada orang lain. Kejujuran menjadi penting karena dengan mengakui apa yang dia pikirkan, ia rasakan, dan dia lakukan sebagaimana adanya seseorang dapat terhindar dari rasa bersalah yang timbul akibat kebohongan yang dilakukan.

Kemendiknas (Wibowo, 2012:71) mengungkapkan bahwa nilai-nilai pendidikan karakter yang perlu diinternalisasikan salah satunya adalah kejujuran. Jujur adalah perilaku yang berdasarkan pada upaya menjadikan dirinya sebagai orang yang selalu dapat dipercaya dalam perkataan, tindakan dan pekerjaan.

Siapa yang memiliki perilaku kejujuran pintu kebaikan akan terbuka, kemudian siapa yang berperilaku tidak jujur lajur kejahatan juga terbuka lebar (Sudewa. E, 2011: 83). Pendapat diatas dapat diartikan bahwa anak yang suka melakukan hal-hal yang tidak jujur akan mengalami kerugian sendiri, hal ini terlihat dalam kualitas hasil pekerjaannya baikyang jujur dan tidak jujur. Setiap orang memiliki karakter yang unik, masing-masing mempunyai karakter yang berbeda tidak sama antara satu dengan yang lainya. Setiap karakter memiliki ciri yang berbeda, baik karakter jujur, tanggung jawab, dan lain- lainya Orang yang memiliki karakter jujur dicirikan oleh perilaku berikut (Kusuma, dkk, 2013: 17):

a. Jika bertekad (inisiasi keputusan) untuk melakukan sesuatu, tekadnya adalah kebenaran dan kemaslahatan.

b. Jika berkata tidak berbohong (benar apa adanya).

c. Jika ada kesamaan antara yang dikatakan hatinya dengan apa yang dilakukanya. 


\section{Pembiasaan Kejujuran}

Menurut Sadewa (2011: 84) melatih kejujuran pada anak tidaklah sulit hal utama yang harus diketahui adalah konsep kepemilikan. Anak harus ditanamkan sejak usia dini apabila menginginkan kepunyaan orang lain haruslah meminta ijin kepada orang yang memiliki barang tersebut. Menanamkan nilai Kejujuran pada anak usia dini merupakan hal yang sangat penting dalam membentuk sikap dan perilaku anak di masa yang akan datang. Setiap orangtua selalu ingin anaknya mempunyai perilaku jujur, ketika anak berkata bohong orang tua akan shock dan berpikir keras untuk mengatasinya. Pada saat anak sudah mulai berbohong orang tua tidak diperbolehkan untuk marah. Orang tua maupun guru dapat menghadapi kebohongan anak usia dini tersebut dengan sikap rileks dan menganggapnya sebagai dongeng. Kebohongan pada anak merupakan hal yang normal bagi perkembangan moral pada anak. Orangtua tidak boleh memberikan hukuman pada anak ketika anak berbohong tetapi harus memberikan pengertian dan alasan untuk tidak berbohong. Orangtua harus menjelaskan pada anak apabila perilaku berbohong akan merugikan dirinya sendiri dan membuat orang lain tidak akan percaya pada yang telah dikatakan. Menurut Rahmah (2012:97) membiasakan jujur pada anak dapat dilakukan dengan:

a. Jamin Dia Aman Berkata Jujur Seorang anak akan merasa aman untuk berkata jujur, apabila semua orang disekitar anak kita dapat menghargai kejujuran yang dilakukan oleh anak tersebut. Tidak marah pada anak ketika anak telah mengakui kesalahannya, karena dengan anak mengakui kesalahanya ia akan berfikir bahwa kejujuran hanya akan berakibat negatif baginya dan sebaiknya kita mengucapkan terimakasih karena anak telah berkata jujur maka akan terbangun image positif pada anak.

b. Perilaku orangtua dan lingkungan pada anak yang teah berkata jujur akan mempengaruhi perilaku seorang anak. Apabila anak melakukan kesalahan dan berkata jujur orang tua memarahi anak tersebut maka anak akan merasa takut untuk berkata jujur. Memberi rasa aman kepada anak untuk berkata jujur dan penjelasan yang mudah tentang pentingnya kejujuran akan memberikan dorongan pada anak untuk tidak berkata bohong lagi.

c. Selain dengan memberikan rasa aman, orangtua dan lingkungan anak dapat menggunakan metode reward. Dengan memberikan penghargaan dan hadiah 
terhadap anak yang telah berperilaku jujur. Tetapi sebelum menentukan hadiah harus dilakukan kesepakatan terlebih dahulu hadiah akan diberikan jika anak telah berapa kali melakukan kejujuran. dengan pemberian hadiah akan menjadikan seorang anak menjadi bangga terhadap kejujuranya.

d. Tanamkan Bahwa Allah Maha

Melihat dan Maha Mendengar

Setiap anak pernah berbohong, tetapi ada anak yang berbohong karena situasi mendesak dan ada juga tang berbohong karena menjadikanya sebagai kebiasaan yang pada akhirnya anakn membawa kehancuran di masa depan anak tersebut. Mengatasi seorang anak yang berbohong tidaklah mudah, karena meneliti berbagai alasan dan penyebab yang mungkin mendorong seorang anak untuk berkata bohong

Ketidakjujuran anak merupakan pelanggaran atau kebohongan yang dilakukan oleh anak-anak. Menurut Hurlock $(1978,104)$ ketidakjujuran dalam berbagai bentuk merupakan pelanggaran.

Menurut Ibung (2009, 71) kebiasaan berbohong pada anak dapat dilakukan dengan beberapa bentuk yaitu:

a. Memutarbalikan keadaan.

b. Melebih-lebihkan, anak menceritakan sesuatu dengan mengombinasikan antara kebenaran dan khayalannya.

c. Membual, anak menceritakan sesuatu yang tidak ia lakukan atau tidak ia alami, dengan seolah-olah ia sendiri mengalami atau merasakanya.

d. Melepas tanggung jawab dengan melemparkan kesalahan diri sendiri pada orang lain termasuk di dalamnya adalah fitnah.

Ketidakjujuran atau berbohong yang dilakukan anak karena mereka punya alasan ingin menguji kemampuan diri, keinginan untuk memiliki kekuasaan atas dirinya sendiri, menutupi ketidaktahuanya bahwa ia telah berbuat sesuatu yang "buruk" atau tidak baik dan bentuk perlindungan diri, kurang parcaya diri. Kebohongan juga dilakukan dalam berbagai

bentuk yaitu memutarbalikan keadaan, melebih-lebihkan, membual, dan melepas tanggung jawab. 


\section{Penyebab Anak Tidak Jujur atau}

\section{Berbohong}

Berbohong pada anak prasekolah merupakan bagian dari masalah dalam aspek perkembangan moral. Konsep benar dan salah akan muncul pada anak usia 3-4 tahun (Rahmah, 2012: 43). Munculnya berbohong pada usia tersebut adalah proses membentuk kenyataan dengan apa yang dia inginkan. Alasan lain untuk anak berbohong adalah mereka merasa tidak berdaya menyembunyikan kebenaranya, dan menghindari hukuman dari orangtua dan lingkungan sekitar. Hal yang bersifat umum ketika seorang anak usia prasekolah berbohong tentang sesuatu, tetapi sebagai orang-orang disekitarnya sebaiknya memperhatikan penyebab mengapa anak berbohong. Menurut Ibung (2009, 73) alasan anak untuk tidak jujur atau berbohong adalah sebagai berikut:

a. Ingin menguji kemampuan diri. b. Menghindar dari hukuman orangtuanya.

c. Cara ini digunakan untuk melupakan sesuatu yang tidak menyenangkan yang pernah dialami. Rahmah (2012: 44) juga berpendapat

ada beberapa penyebab seorang anak berbohong atau melakukan tindakan tidak jujur adalah sebagai berikut:

a. Anak berbohong untuk melihat reaksi lawan bicaranya, yang biasanya dalam hai ini adalah orang tuanya.

b. Berbohong untuk membesar- besarkan dirinya, yang sengaja dilakukan untuk meningkatkan rasa percaya diri di mata teman-temanya dengan harapan diperhitungkan di mata teman-temanya dan kelompok

c. Berbohong muncul pula karena imajinasinya yang berkembang pesat atau dapat dikatakan dusta putih. Padahal, sesungguhnya secara sadar dia tidak ingin berbohong. Dusta ini sering dilakukan oleh anak-anak prasekolah dan anak-anak kelas 1

SD. Setelah anak lebih dari kelas 1

SD maka tidak dapat dikatakan sebagai dusta putih lagi karena anak sudah dapat membedakan khayalan dan kenyataan

d. Berbohong juga dapat dilakukan anak untuk menutupi perbuatanya. Misalnya, ketika anak melakukan kesalahan anak langsung mencari kambing hitam untuk menutupi kesalahnya 
e. Berbohong juga dapat karena imitasi berbohong, di mana anak berbohong karena ingin meniru orang lain. Anak meniru tindakan-tindakan yang dilakukan oleh orangorang disekitarnya, terutama orangtua. Jadi

jangan heran jika orangtua pembohong maka anak juga pembohong.

f. Berbohong karena ingin pujian. Anak melakukan kebohongan karena ingin mendapat pujian dari orang-orang di sekitarnya, walaupun anak harus berbohong tentang hal-hal yang tidak dilakukanya

\section{Cara Orangtua Membentuk Karakter}

\section{Jujur Pada Anak}

Karakter kejujuran merupakan pilar penting dalam pembentukan perilaku seseorang. Karakter kejujuran ini harus ditanamkan sejak anak masih usia dini. Ada beberapa cara orangtua untuk membentuk karakter kejujuran (Isna, 2012: 37):

a. Hindari memberikan label "pembohong" kepada anak meskipun dia melakukan kebohongan.

b. Jangan Bohongi Anak

c. Jangan Memberi Contoh Berbohong

Berbagai cara yang dapat dilakukan orangtau untuk membentuk perilaku kejujuran pada anak mulai dari tidak memberikan labeling pada anak, karena pemberian labeling akan membentuk kepercayaan terhadap label tersebut. Kemudian jangan menanyakan sesuatu yang sudah diketahui jawabanya dan jangan tanyakan sesuatu yang anak tidak ingin menjawab. Selain itu jangan memarahi anak, ajarkan anak untuk berperilaku jujur

dan berikan pujian jika anak berperilaku jujur. Cara ini dapat membentu anak agar dapat berperilaku jujur dan akan membentuk generasi penerus bangsa selain itu penanaman nilai kejujuran dapat dilakukan dengan penggunaan media dalam pembelajaran.

Selain itu Rahmah (2012:99) juga menjelaskan ada bebrapa larangan yang tidak boleh dilakukan orangtua dalam membentuk sikap jujur pada anak:

a. Jangan Memojokkan Anak. b. Jangan Emosi

\section{Indikator-indikator Jujur AUD}

Berdasarkan pedoman pendidikan karakter pada pendidikan anak usia dini oleh direktorat pembinaan pendidikan anak usia dini, direktorat jenderal pendidikan anak 
usia dini, nonformal, dan informal, kementrian pendidikan nasional (2012) terdapat sembilan indikator untuk nilai atau karakter kejujuran yaitu:
a) Anak mengerti mana milik pribadi dan milik bersama
b) Anak merawat dan menjaga benda milik bersama
c) Anak terbiasa berkata jujur
d) Anak terbiasa mengembalikan benda yang bukan miliknya
e) Menghargai milik orang lain f) Mau mengakui kesalahan
g) Mau meminta maaf dan memaafkan teman yang berbuat salah
h) Menghargai keunggulan orang lain
i) Tidak menumpuk mainan atau makanan untuk diri sendiri.

\section{Media Pembelajaran}

Menurut bahasa, media berasal dari kata/bahasa latin dan merupakan bentuk jamak dari kata medium, yang secara harfiah berarti perantara atau pengantar. Media adalah perantara atau pengantar pesan dari pengirim ke penerima pesan (dalam Sanjaya, 2006: 132) Sedangkan menurut National Education Association (NEA), media sebagai segala benda yang dapat dimanipulasi, dilihat, didengar, dibaca atau dibicarakan beserta instrument yang dipergunakan untuk kegiatan tersebut. Gagne (dalam Arief Sadiman dkk, 2009) menyatakan bahwa media adalah berbagai jenis komponen dalam lingkungan mahasiswa yang dapat merangsang mahasiswa untuk belajar.

Media pembelajaran dapat menyederhanakan materi pembelajaran, mendekatkan dengan mahasiswa dan mengongkritkan konsep yang akan disampaikan oleh dosen. Media dapat dijadikan sebagai jembatan sebelum mahasiswa akan melakukan praktik. Peneliti beranggapan bahwa mahasiswa memerlukan media kreatif yang dapat mengaktifkan atau melibatkan partisipasi mahasiswa secara langsung dan bukan hanya melalui power pointsaja (menurut Septiana Pradina. 2009)

Dari uraian diatas dapat disimpulkan bahwa media pembelajaran adalah benda atau alat yang digunakan untuk menyalurkan pesan sehingga dapat merangsang pikiran, perasaan, perhatian dan kemauan mahasiswa, mengefesiensikan, mengefektifkan proses dan hasil belajar, dan dapat mendorong terjadinya proses belajar pada diri mahasiswa. Penggunaan media secara kreatif akan mengakibatkan mahasiswa belajar lebih banyak. 


\section{Fungsi Media Pembelajaran}

Media pembelajaran mempunyai beberapa fungsi yang dapat kita manfaatkan sebelum Proses Belajar Mengajar(PBM) berlangsung. Menurut Hamim (2011: 80) sebelum kita membuat sebuah media pembelajaran kita harus mengetahui dahulu konsep abstrak dan konkrit dalam pembelajaran. Karena proses belajar mengajar hakekatnya adalah proses komunikasi, penyampaian pesan dari pengantar dan penerima. Adapun fungsi media pembelajaran adalah sebagai berikut. a. Media pembelajaran dapat mengatasi keterbatasan pengalaman yang dimiliki oleh para peserta didik. Pengalaman peserta didik berbedabeda, tergantung dari faktor-faktor yang menentukan kekayaan pengalaman anak, seperti ketersediaan buku, kesempatan

melancong, dan sebagainya. Media pembelajaran dapat mengatasi hal tersebut. Jika peserta didik tidak mungkin dibawa ke obyek langsung, maka obyeknya lah yang di bawa ke peserta didik. Obyek dimaksud adalah dalam bentuk nyata, miniatur, model, maupun bentuk-bentuk gambar yang dapat disajikan secara audio visual dan audial.

b. Media pembelajaran dapat melampaui batasan ruang kelas.

c. Media pembelajaran memungkinkan adanya interaksi langsung antara peserta didik dengan lingkunganya.

d. Media menghasilkan keseragaman pengamatan.

e. Media dapat menanamkan konsep dasar yang benar, konkrit, dan realistis.

f. Media dapat membangkitkan keinginan dan minat baru.

g. Media membangkitkan motivasi dan merangsang anak untuk belajar.

h. Media memberikan pengalaman yang integral/menyeluruh dari yang konkrit sampai dengan abstrak.

\section{Media Ular Tangga}

Permainan ular tangga merupakan kegiatan bermain, anak sesungguhnya belajar permainan (games) untuk mengeksploitasi dan merekayasa berbagai hal serta berinteraksi satu sama lain yang dapat dilakukannya dengan mengikuti aturan - aturan tertentu. Para pemain yang sama, bermain dengan meletakkan bidak pada papan permainan ular yang bertuliskan kata "Strat" selanjutnya tiap pemain mengocok dadu untuk menentukan berapa langkah yang harus dijalankan. Setelah berhenti di salah satu kotak, pemain dapat 
langsung menebak nama suatu aktivitas yang langsung,spontan, langkah permainan diatas dilakukan oleh pemain secara bergantian hingga berakhir, dilakukan dengan di kotak yang bertuliskan kata "Finish".

\section{METODOLOGI}

Penelitian dilakukan di PAUD Cahaya semester 2, pada semester genap 2016/2017. Subjek Penelitian ini adalah anak PAUD semester 2 yang berjumlah 9 anak dengan tingkat kemampuan heterogen. Untuk menganalisis data menggunakan interactive model yang dikemukakan Miles, terdapat tiga langkah yaitu data reduksi, penyajian data, dan penarikan kesimpulan. Data diperoleh dengan tiga teknik pengumpulan data yaitu wawancara, observasi, dan dokumentasi. Wawancara menggunakan jenis wawancara terstruktur karena peneliti sudah menyiapkan pertanyan-pertanyaan berkaitan dengan apa yang akan diteliti. Observasi yang digunakan menggunakan jenis observasi berperan serta karena peneliti ikut dalam

kegiatan pembelajaran tetapi tidak mengajar hanya melakukan pengamatan. Setelah data terkumpul dan dianalisis selanjutnya di uji keabsahannya dengan uji triangulasi, yang menggunakan jenis triangulasi teknik yang berarti menggunakan teknik yang berbedabeda untuk mengumpulkan data yang sama.

\section{HASIL DAN PEMBAHASAN}

Penelitian ini menggunakan teknik pengumpulan data wawancara, observasi, dan dokumentasi. Yang akan meneliti kejujuran anak. Indikator yang akan dibahas dalam penelitian ini diantaranya:

Tabel 4.1 Indikator Kejujuran

\begin{tabular}{|c|c|c|}
\hline $\begin{array}{l}\text { Variabel } \\
\text { Penelitian }\end{array}$ & Aspek & Indikator \\
\hline \multirow{4}{*}{$\begin{array}{l}\text { Karakter } \\
\text { Kejujuran } \\
\text { (Pedoman } \\
\text { Pendidikan Karakter } \\
\text { pada Pendidikan } \\
\text { Anak Usia Dini }\end{array}$} & \multirow{4}{*}{$\begin{array}{l}\text { Keadaan } \\
\text { yang keadaan } \\
\text { terkait dengan } \\
\text { ketulusan dan } \\
\text { kelurusan hati } \\
\text { berbuat benar }\end{array}$} & $\begin{array}{l}\text { 1. Anak merawat dan menjaga benda } \\
\text { milik bersama }\end{array}$ \\
\hline & & 2. Anak terbiasa berkata jujur \\
\hline & & 3. Mau mengakui kesalaha $\mathrm{n}$ \\
\hline & & $\begin{array}{l}\text { 4. Mau minta maaf bila salah, dan } \\
\text { memaafk an teman yang berbuat }\end{array}$ \\
\hline
\end{tabular}


Dari hasil penelitian yang menggunakan tiga teknik pengumpulan data dengan indikator di atas yang selanjutnya akan digunakan untuk uji kredibilitas dengan triangulasi teknik memperoleh data sebagai berikut:

Tabel 4.2 Kejujuran Anak

\begin{tabular}{|l|l|c|c|c|c|}
\hline \multirow{2}{*}{ No } & \multirow{2}{*}{ Nama Anak } & \multicolumn{5}{|c|}{ Indikator Kejujuran Anak } \\
\cline { 3 - 6 } & & $\mathbf{a}$ & $\mathbf{b}$ & $\mathbf{c}$ & $\mathbf{d}$ \\
\hline 1 & R1 & 4 & 3 & 3 & 3 \\
\hline 2 & R2 & 3 & 3 & 3 & 3 \\
\hline 3 & R3 & 4 & 4 & 3 & 4 \\
\hline 4 & R4 & 4 & 4 & 3 & 4 \\
\hline 5 & R5 & 4 & 4 & 4 & 4 \\
\hline 6 & R6 & 4 & 4 & 4 & 3 \\
\hline 7 & R7 & 3 & 3 & 3 & 3 \\
\hline 8 & R8 & 3 & 3 & 4 & 4 \\
\hline 9 & R9 & 3 & 3 & 3 & 3 \\
\hline
\end{tabular}

Berdasarkan hasil penelitian dari keempat indikator kejujuran banyak anak yang sudah memperoleh kriteria keempat yaitu berkembang sangat baik, yang lain memperoleh kriteria ketiga yaitu berkembang sesuai harapan. Jadi penanaman kejujuran anak menggunakan media ular tangga pada anak PAUD Cahaya berada dalam tahap berkembang sesuai harapan (3) dan berkembang sangat baik (4). Sudah tidak anak anak yang mendapatkan kriteria kedua (2) yaitu mulai berkembang dan kesatu (1) belum berkembang.

Strategi yang dilakukan guru dalam penanaman kejujuran anak di PAUD Cahaya adalah dengan penggunaan media yang menarik dalam pembelajaran yaitu media ular tangga. Dengan menggunaan media yang tepat dalam pembelajaran dapat merangsang anak untuk mengeksploitasi dan merekayasa berbagai hal serta berinteraksi satu sama lain yang dapat dilakukannya dengan mengikuti aturan- aturan tertentu dalam pembelajaran melalui bermain. Disamping itu, dengan media ular tangga guru juga 
memberikan pembiasaan kepada anak untuk berkata jujur. Seperti ketika anak melakukan kesalahan anak diajarkan untuk mengakui kesalahannya, anak juga dibiasakan untuk mau memaafkan kesalahan teman. Ketika dalam sebuah permainan ular tangga anak juga diajarkan untuk dapat merawat dan menjaga barang-barang milik bersama dengan baik contohnya media ular tangga yang digunakan untuk permainan tidak boleh dicoret-coret, disobek, dibuang serta menjaga perlengkapan (dadu dan papan ulartangga). Anak juga harus merapikan media ular tangga yang telah digunakan untuk disimpan kembali pada tempatnya. Hal ini sesuai dengan yang dikemukakan oleh Gerlach dan Ely (Sanjaya, 2010) menyatakan bahwa media adalah manusia, materi, atau kejadian yang membangun kondisi yang membuat siswa mampu memperoleh pengetahuan, keterampilan, atau sikap.

Jadi kesimpulannya penanaman kejujuran pada anak PAUD Cahaya

Surabaya sudah berada dalam tahap berkembang sesuai harapan. Berdasarkan analisis dari peneliti bahwa kejujuran pada anak usia dini perlu ditanamkan sejak dini melalui pembiasaan yang berulang-ulang. Disamping itu strategi pembelajaran di sekolah juga sangat mempengaruhi perkembangan kejujuran anak.

\section{PENUTUP}

Kejujuran merupakan suatu kemampuan untuk mengakui perasaan atau pemikiran atau juga tindakan seseoarang kepada orang lain. Kejujuran sangat penting ditanamkan pada anak sejak dini dalam membentuk sikap dan perilaku anak di masa yang akan datang. Kejujuran pada anak usia dini meliputi 1) anak mengerti mana milik pribadi dan milik bersama, 2) anak merawat dan menjaga benda milik bersama, 3) anak terbiasa berkata jujur, 4) anak terbiasa mengembalikan benda yang bukan miliknya, 5) menghargai milik orang lain, 6) mau mengakui kesalahan, 7) mau meminta maaf dan memaafkan teman yang berbuat salah, 8) menghargai keunggulan orang lain,dan 9) tidak menumpuk mainan atau makanan untuk diri sendiri.

Penanaman kejujuran pada anak usai dini dapat dilakukan melalui kegiatan pembelajaran yang menggunakan media yang menarik bagi anak. Sesui dengan pendapat Gagne yang menyatakan bahwa media adalah berbagai jenis komponen dalam lingkungan siswa yang dapat merangsang siswa untuk belajar. Salah satunya dapat merangsang anak untuk belajar kejujuran. Media tersebut salah satunya adalah media ular tangga. permainan dengan media ulartangga anak dapat mengeksploitasi dan 
merekayasa berbagai hal serta berinteraksi satu sama lain yang dapat dilakukannya dengan mengikuti aturan- aturan tertentu.

\section{REFERENSI}

Arikunto, Suharsimi. 2006. Prosedur Penelitian Suatu Pendekatan Praktik. Jakarta: Rineka Cipta.

Depertemen Pendidikan dan Kebudayaan. Kamus Besar Bahasa Indonesia. Jakarta: Balai Pustaka.

Dorothy L. Prestwich. 2003 Character Education in America's Schools. The School Community Journal, Volume 5, Issue 1. [March, 2003].

Hidayatullah, M Furqon. 2010. Pendidikan Karakter (Membangun Peradapan Bangsa). Surakarta: Yuma Pustaka.

Hurlock, Elizabeth B. 1978. Perkembangan Anak Jilid 2. Jakarta: Erlangga.

Ibung, D. 2009. Mengembangkan Nilai Moral pada Anak. Jakarta: PT Elex Media Komputindo Kelompok Gramedia.

Isna, Nurla. 2012. Mencetak Karakter Anak Sejak Janin. Yogyakarta: Diva Pers 


\title{
Permainan Monyet Dan Pohon Untuk Menstimulus Perkembangan Anak Usia Dini
}

\author{
Dian Anggraini ${ }^{1}$, Andini Dwi Arumsari ${ }^{2}$ \\ ${ }^{1}$ Mahasiswa Program Studi PG PAUD FKIP Universitas Narotama \\ ${ }^{2}$ Dosen Program Studi PG PAUD FKIP Universitas Narotama \\ Anggraini54@gmail.com
}

\begin{abstract}
ABSTRAK
Bermain dan permaianan adalah hal yang disukai anak-anak terutama anak usia dini. Melalui bermain seorang anak dapat belajar berbagai hal baru yang belum ia ketahui sebelumnya. Pada penelitian kali ini penulis ingin berbagi ide permainan yang bisa digunakan guru disekolah untuk melatih dan menstimulus perkembangan anak usia dini dari berbagai aspek, salah satunya adalah dengan menggunakan permainan monyet dan pohon. Permainan fisik yang menyenangkan ini tidak hanya membuat anak menjadi sehat dan kuat ototnya melainkan banyak aspek yang dapat dikembangkan. Permainan pohon dan monyet ini mempu meningkatkan kemampuan anak pada aspek agama dan moral, fisik motoric, kognitif, bahasa, sosial emosional dan seni. Jenis penelitian yang digunakan adalah deskriptif naratif. Hasilnya sesuai dengan pendapat para ahli perihal bermain, permainan monyet dan pohon ini dapat menstimulus 6 aspek perkembangan anak usia dini, yaitu kognitif, motoric, sosial emosional, bahasa, seni, moral dan agama.
\end{abstract}

Kata Kunci: permainan monyet dan pohon, perkembangan anak, bermain dan permainan.

\begin{abstract}
Play and games are what kids love, especially early childhood. Through playing a child can learn various new things that he did not know before. In this research the author wants to share ideas of games that can be used by school teachers to train and stimulate early childhood development from various aspects, one of which is to use monkey and tree games. This fun physical game not only makes children healthy and strong muscles but many aspects that can be developed. This game of trees and monkeys can improve children's abilities in religious and moral aspects, physical motoric, cognitive, language, social emotional and artistic aspects. This type of research is descriptive narrative. The results are in accordance with the opinions of experts regarding playing, this monkey and tree game can stimulate 6 aspects of early childhood development, namely cognitive, motoric, social emotional, language, art, moral and religion.
\end{abstract}

Key words: monkey and tree games, child development, play and games 


\section{PENDAHULUAN}

Anak usia dini adalah anak yang berusia 0 sampai 6 tahun. Pada usia ini, seringkali disebut sebagai masa keemasan atau golden age. Di masa ini, adalah masa yang paling menentukan pada perkembangan anak, terutama perkembangan otak anak. Oleh sebab itu, anak perlu diberikan perhatian yang lebih banyak, seperti memberikan stimulus yang tepat untuk tumbuh kembang anak, dan memberikan pendidikan yang baik untuk anak. Pendidikan yang baik bisa diberikan oleh orang tua sendiri maupun oleh lembaga pendidikan untuk anak usia dini. Hal tersebut dikarenakan, tumbuh kembang anak di usia golden age tersebut menjadi penentu bagi perkembangan anak selanjutnya (Fauziddin, 2016). Tujuan Pendidikan Anak Usia Dini (PAUD) menurut UndangUndang nomor 20 tahun 2003 tentang sistem pendidikan nasional dinyatakan bahwa pendidikan anak usia dini adalah sebagai suatu upaya pembinaan yang ditujukan kepada anak sejak lahir sampai dengan usia enam tahun yang dilakukan melalui pemberian rangsangan pendidikan untuk membantu pertumbuhan dan perkembangan jasmani dan rohani agar anak memiliki kesiapan dalam memasuki pendidikan lebih lanjut (Indonesia, 2003). Hal tersebut juga sejalan dengan pendapat Bloom (dalam Sari \& Arumsari, 2019) yang menyatakan bahwa pendidikan pada anak usia dini akan memberikan dampak pada pertumbuhan anak pada fase selanjutnya. Namun, data yang didapat oleh Depdiknas tahun 2002 (dalam Arumsari dkk, 2017), baru 28\% dari 26,1 juta anak usia 0-6 tahun yang mendapat pendidikan usia dini.

Bermain adalah serangkaian kegiatan atau aktivitas anak untuk bersenang-senang. Berbagai kegiatan yang dapat membuat anak bahagia dan senang, maka bisa dikatakan sebagai bermain. Seperti yang tercantum dalam Kamus Besar Bahasa Indonesia (2008:857) bermain berasal dari kata dasar main yang berarti melakukan aktivitas atau kegiatan untuk menyenangkan hati. Bermain dalam konteks ini perlu bertujuan untuk membuat anak merasa senang, nyaman, ceria dan bersemangat.

Piaget berpendapat bahwa sekalipun kegiatan tersebut sudah sering dilakukan namun masih tetap terasa menyenangkan atau memberi kepuasan bagi diri seseorang. Menurut Parten, bermain adalah suatu kegiatan sebagai sarana bersosialisasi, menemukan, mengekspresikan perasaan, berkreasi, dan belajar dengan cara yang menyenangkan. Docket dan Fleer mengatakan, bahwa seorang anak butuh bermain, karena dengan bermain anak akan mendapatkan pengetahuan yang bisa mengembangkan kemampuan dirinya. Menurut Mayesty, bermain merupakan kegiatan yang anak-anak lakukan sepanjang hari, karena bagi anak bermain adalah hidup dan hidup adalah bermain.

Berdasarkan beberapa pendapat diatas, dapat dipahami bahwa bermain ialah suatu upaya untuk memperoleh kesenangan dan kepuasan jiwa dari setiap aktivitas yang dilakukan, baik menggunakan alat permainan maupun tidak. Yang terpenting anak merasa gembira dengan permainan yang dilakukannya, serta tidak begitu memedulikan tentang hasil akhir yang didapatkan. Namun bagi anak usia dini bentuk dan alat permainan harus memiliki nilai-nilai edukatif, dalam rangka sebagai sarana mengembangkan potensi anak-anak.

Bermain merupakan kebutuhan alamiah anak usia dini. Selain sebagai aktivitas bersenang-senang, bermain juga dimaksudkan untuk belajar anak. Karena memang belajarnya anak melalui aktivitas bermain. Jadi bermain bagi anak usia dini memiliki kedudukan yang sangat penting. Banyak manfaat yang bisa diperoleh dari kegiatan bermain. Oleh Karena itu, bermain tidak bisa dipisahkan dari anak usia dini. 
Bermain menjadi prioritas utama dalam kegiatan pembelajaran anak usia dini. Melalui bermain seorang anak dapat belajar berbagai hal baru yang belum ia ketahui sebelumnya. Selain itu, bermain dapat menstimulasi berbagai perkembangan anak, seperti fisik - motorik, kognitif, logika - matematika, Bahasa, moral - agama, sosial emosional dan seni. Melalui bermain pula kreativitas anak akan terbangun dan berkembang dengan maksimal.

Bermain menurut Al - Ghazali adalah hal yang sangat penting bagi anak, sebab melarang anak bermain dapat membuat hatinya mati, kecerdasannya terganggu dan merusak irama hidupnya. Dengan kata lain, bermain adalah dunia anak - anak. Maka wajar saja bila anak cenderung merasa antusia dalam bermain. Bahkan seolah - olah tidak mempunyai rasa lelah dan sampai lupa waktu. Sutton Smith ( dalam Hurlock, 1987) menjelaskan bahwa bermain memiliki pengaruh yang sangat penting bagi anak, yakni sebagai dasar meniru, eksplorasi, menguji, dan membangun.

Plato, seorang tokoh filsuf yang dianggap sebagai orang yang pertama sadar dan melihat betapa pentingnya nilai praktis dari bermain, berpendapat bahwa akan lebih mudah mengajarkan aritmatika kepada anak-anak dengan cara membagikan apel kepada mereka (Diana, 2010:92). Aristoteles dan Frobel mengemukakan bahwa bermain sebagai kegiatan yang mempunyai nilai praktis. Bermain dapat dipakai untuk media sebagai upaya meningkatkan keterampilan dan kemampuan pada anak. Selanjutnya Frobel menekankan bahwasanya bermain dalam belajar itu penting, karena menurut pengalamannya saat menjadi guru, dia sadar bahwa baik bermain maupun mainan yang dinikmati anak bisa dijadikan alat untuk menarik perhatian dan mengembangkan pengetahuan mereka (Diana : 92 - 93).

Ailwood (2003) menyatakan bahwa: Play in early childhood education forms a significant nodal point at which understanding and discourses of childhood, motherhood, education, family, psychology, and citizenship coagulate and collide. Dari pernyataan diatas dapat diketahui bahwa ketika anak-anak bermain di sekolah (Pendidikan Anak Usia Dini) terjadi interaksi sosial antara anak-anak, guru, orang tua, dunia pendidikan, keluarga, psikolog, bahkan dengan orang-orang yang ada di dunia pemerintahan.

Beberapa alasan yang mendasari pentingnya bermain, diantaranya: a) cara belajar anak yang paling efektif adalah dengan cara bermain, b) bermain dapat meningkatkan penalaran dan memahami keberadaannya di lingkungan teman sebaya dan membentuk daya imajinasi, c) melalui bermain anak dapat mempelajari dan belajar banyak hal, d) dapat mengenal aturan, kerja sama, disiplin, dan lain-lain, e) bermain adalah cara yang paling baik dan tepat untuk mengembangkan kemampuan anak usia dini dan f) Menurut konsep edutainment, belajar tidak akan berhasil dalam arti yang sesungguhnya bila dilakukan dalam keadaan yang menegangkan dan menakutkan, belajar hanya akan efektif bila suasana hati anak sedang dalam kondisi yang menyenangkan.

Utami Munandar menyebutkan bahwa bermain sebagai kegiatan yang dapat membantu anak mencapai perkembangan yang utuh, baik fisik, intelektual, sosial, moral dan emosional. Berbagai perkembangan anak tersebut dapat diperoleh melalui berbagai kegiatan bermain yang dilakukan anak, baik sendiri maupun bersama-sama dengan teman sebayanya. Wolfgan juga berpendapat bahwa terdapat sejumlah nilai-nilai dalam bermain (the value of play) yaitu bermain dapat mengembangkan keterampilan sosial, emosional dan kognitif (yuliani, 2009:145) 
Slamet suyanto (2015:124-126) berpendapat bahwa bermain mempunyai peranan penting dalam perkembangan anak hamper pada semua bidang perkembangan, yaitu perkembangan fisik-motorik, Bahasa, intelektual, moral, sosial, dan emosional. Lebih lanjut mengenai peran bermain untuk perkembangan anak dapat dilihat melalui uraian berikut ini:

1. Bermain mengembangkan kemampuan motoric

Piaget berpendapat bahwa anak terlahir dengan kemampuan refleks, lali dia belajar untuk menggabungkan dua atau lebih gerakan refleks yang pada akhirnya dia mampu mengontrol gerakannya. Dengan bermain gerakan anak bisa lebih terkontrol dan terkoordinir dengan baik. Selain itu, bermain bisa membuat anak bebas untuk bergerak, sehingga kemampuan motoriknya dapat berkembang.

2. Bermain mengembangkan kemampuan kognitif

Piaget berpendapat bahwa anak belajar mengkonstruksikan pengetahuan dengan berinteraksi dengan objek yang ada disekitarnya. Dengan bermain anak akan mendapatkan kesempatan untuk berinteraksi dengan berbagai objek. Anak dapat menggunakan semua inderanya seperti menyentuh, mencium, melihat dan mendengarkan, untuk mengetahui sifat - sifat objek. Dalam konsep edutainmet hal ini disebut sebagai global learning (belajar menyeluruh)

3. Bermain mengembangkan kemampuan afektif

Kemampuan afektif adalah kemampuan yang berhubungan dengan sikap seseorang. Kemampuan ini dapat dikembangkan dan dilatih melalui kegiatan bermain. Caranya yaitu dengan melaksanakan dan mengikuti aturan - aturan permainan yang telah disepakati bersama. Karena dalam setiap permainan pasti memiliki aturan. Aturan tersebut akan dikenalkan oleh teman bermain sedikit demi sedikit, secara bertahap sampai anak memahaminya. Oleh karena itu, bermian akan melatih anak dalam menyadari akan adanya aturan dan pentinya mematuhi aturan. Yang demikian itu merupakan tahap awal dari perkembangan moral anak.

4. Bermain mengembangkan kemampuan Bahasa

Ketika bermain anak akan menggunakan Bahasa,baik untuk berkomunikasi atau hanya sekedar menyatakan pikirannya. Vigotsky dalam slamet suyanto (2005:125) menyebutkan bahwa bermain dengan bercakap-cakap menggambarkan anak sedang dalam tahap menggabungkan pikiran dan Bahasa sebagai satu kesatuan. Jadi dengan bermain secara otomatis kemampuan berbahasanya dapat berkembang dengan baik.

5. Bermain mengembangkan kemampuan social

Ketika bermain anak secara langsung berinteraksi dengan anak lain. Dari interaksi tersebut anak dapat belajar bagaimana memberi respon, memberi dan menerima, menolak atau menyetujui ide dan perilaku anak yang lain. Sikap yang demikian dapat mengurangi sifat egosentris pada anak dan kemampuan sosialnya dapat berkembang dengan baik juga.

Selain kelima aspek perkembangan diatas masih ada aspek perkembangan lain yaitu imajinasi, seni, kreativitas, dan moral agama. Dengan bermain segala aspek perkembangan anak akan dapat terstimulasi dengan baik. Prinsip bermain dalam pendidikan anak usia dini antara lain : memiliki tujuan yang jelas, dilakukan secara 
bebas, mementingkan proses bukan hasil, memperhatikan keselamatan, serta menyenangkan dan dapt dinikmati.

Penelitian ini akan difokuskan pada permainan monyet dan pohon untuk menstimulasi perkembangan anak usia dini.permainan fisik yang menyenangkan ini tidak hanya membuat anak menjadi sehat dan kuat ototnya melainkan banyak aspek yang dapat dikembangkan. Guna memberikan ide kepada guru-guru paud lainnya agar dapat diterapkan disekolah masing-masing..

Permainan monyet dan pohon adalah permainan yang dirancang untuk mengembangkan aspek fisik motorik, kognitif, sosial emosional, moral agama, Bahasa dan seni pada anak usia dini. Sasaran untuk permainan ini adalah anak usia 5-6 tahun. Permainan ini membutuhkan tiga anak untuk satu tim, Dua orang bergandengan keatas sebagai pohon dan satu anak sebgai monyetnya.dan minimal 6 anak untuk bermain.

Adapun aspek yang dikembangkan pada fisik motorik yaitu anak dapat menggunakan tangan dan kakinya untuk bergerak kesana kemari, sehingga anak menjadi gesit dan lincah. Kemampuan kognitif yang dapat di asah adalah bagaimana anak memecahkan masalah, bagaimana dan kemana dia harus berlari mencari pohon atau monyet agar timnya tidak kalah. Kemampuan sosial emosional tentunya terstimulus dengan permainan ini, anak harus bermain sebagai tim dan bekerja sama dengan baik. Anak juga belajar menghargai pendapat temannya misal temannya ingin menjadi pohon atau monyet, dengan moral yang baik anak akan dapat menghargai satu sama lain. Dalam permainan ini sudah jelas memerlukan adanya kemampuan Bahasa yang baik. Dengan permainan ini anak dapat belajar menyimak perintah atau aba - aba dari guru, berkomunikasi dengan teman dan bahkan mengutarakan ide-idenya dalam permainan. Pada aspek seni, anak belajar memainkan sebuah peran, baik sebagai monyet atau pohon.

Dalam proses bermain permainan monyet dan pohon, guru akan menemui berbagai hal seperti kelas menjadi gaduh karena anak-anak merasa bersemangat, anak tidak mau berganti peran, anak memilih - milih teman, anak tidak menemukan pasangan, anak menginginkan peran yang sama dengan temannya sehingga yang lain tidak kebagian peran. Disinilah peran guru sebagai penengah dibutuhkan, guru harus bisa sebaik mungkin untuk membujuk muridnya dengan kata-kata motivasi, pujian bahkan hadiah bila diperlukan agar anak mau bermain dan mengikuti aturan.

\section{METODOLOGI}

Metode yang digunakan pada penelitian ini adalah metode deskriptif. Muhammad Ali (1982:120) mengemukakan bahwa metode deskriptif adalah "metode yang digunakan untuk memecahkan masalah yang sedang dihadapi pada situasi sekarang yang dilakukan dalam menempuh langkah-langkah pengumpulan data, klarifikasi, dan analisis pengolahan dan membuat gambaran tentanf suatu keadaan secara obyektif dan suatu deskriptif". 


\section{HASIL DAN DISKUSI}

Perkembangan yang dialami anak usia dini (AUD) dapat diberikan melalui stimulus, baik ketika berada di rumah, maupun di luar rumah. Stimulus untuk meningkatkan perkembangan anak bias diberikan melalui pendidikan oleh orang tuanya di rumah maupun pendidikan di sekolah (Pendidikan Anak Usia Dini). Stimulus yang diberikan kepada anak dapat berupa permainan, karena dalam belajar anak bisa melalui bermain dan permainan. Pengaruh bermain sangat besar pada perkembangan anak. Anak-anak bermain dengan hati senang, dan tidak memperdulikan kondisi fisik dan psikisnya sedang dalam keadaan baik atau tidak. Guru sebagai pendidik di sekolah dan orang tua sebagai pendidik di rumah mempunyai peran penting dalam menentukan permainan yang sesuai dengan tingkat perkembangan anak.

Permainan merupakan serangkaian aktivitas yang memunculkan rasa senang yang dilakukan untuk kepentingan kegiatan itu sendiri (Santrock, 2002). Freud mengatakan dalam teori psikoanalisa bahwa bermain mempunyai peran dalam perkembangan seorang anak. Peran yang dimiliki oleh kegiatan bermain pada anak adalah untuk mengatasai pengalaman yang menimbulkan trauma pada anak, dan menangani frustasi. Menurut Piaget dalam teori kognitifnya mengatakan bahwa bermain mempunyai pera pada perkembangan anak, seperti sarana untuk melakukan aktivitas sesuai konsep yang telah dibuat, dan keterampilan yang telah dipelajari sebelumnya. Sedangkan menurut Bateson, bermain mempunyai peran dalam perkembangan anak, yaitu untuk meningkatkan kemampuan anak dalam memahami setiap tingkatan makna (Bateson \& Mead, 1942). Dengan melakukan bermain, informasi yang didapatkan anak menjadi lebih bervariasi, sehingga pengetahuan dan pemahaman yang dimiliki anak menjadi lebih banyak dan mendalam. Jika anak mendapatkan informasi yang berbeda dengan informasi yang diketahui sebelumnya, maka hal tersebut membuat anak memiliki pengetahuan yang baru.

Berdasarkan pendapat para ahli bahwa permainan untuk anak usia dini harus menyenangkan dan mampu mengembangkan ke enam aspek perkembangan. Salah satu permainan yang dapat diberikan kepada anak dengan tujuan untuk meningkatkan perkembangan anak adalah dengan permainan monyet dan pohon. Aturan main monyet dan pohon, yaitu:

1. guru membagi murid-murid menjadi kelompok kecil. Kelompok kecil tersebut terdiri dari 3 (tiga) anak,

2. lalu anak dibagi untuk berperan menjadi pohon dan monyet,

3. dua anak yang menjadi pohon harus berdiri berhadapan sambal bergandeng tangan dan mengangkatnya ke atas seperti bentuk terowongan, kemudian satu anak yang menjadi monyet duduk berjongkok ditengah-tengah terowongan yang disebut pohon,

4. guru menjelaskan aturan bermain pada anak,

5. guru akan memberikan perintah (instruksi) pertama, sebelumnya anak akan diajak untuk menari/ berjoged bersama dan tetap pada posisi,

6. ketika guru berkata "monyet" maka anak yang berperan sebagai monyet harus berpindah tempat mencari pohon lain untuk ditinggali. Sedangkan anak yang berperan sebagai pohon harus diam ditempat, 
7. ketika guru berkata "pohon" maka anak yang berperan sebagai pohon harus berpindah dan mencari monyet lain untuk dilindungi. Anak yang berperan sebagai monyet harus diam ditempat, dan (8) apabila guru berkata "kebakaran" maka setiap anak berhak mengganti perannya dan pasangannya. Misal yang tadinya menjadi pohon berubah menjadi monyet, yang tadinya monyet menjadi pohon, dan yang tadinya si A menjadi pohon bersama si B maka harus bertukar pasangan dengan si C, D atau lainnya. Dan yang paling penting harus membuat tim berisi 3 (tiga) anak.

Dalam permainan monyet dan pohon, stimulus yang didapat oleh anak dapat mencakup seluruh aspek perkembangan pada anak. Adapun aspek perkembangan yang bisa diasah pada permainan monyet dan pohon adalah sebagai berikut:

1. Kognitif: melalui aktivitas bermain, anak mempelajari bermacam-macam konsep bentuk, warna, ukuran dan jumlah yang dapat memberikan stimulasi untuk perkembangan kognitifnya. Dengan bermain, anak juga mampu mempunyai kemampuan memecahkan masalah. Dalam permainan monyet dan pohon, anak mampu mengenal konsep berhitung 1-3 ketika guru meminta anak untuk membuat kelompok yang terdiri dari 3 anak. Anak juga dapat memecahkan masalahnya sendiri ketika guru memberikan instruksi monyet dan anak yang menjadi monyet harus pindah ke tempat lain.

2. Fisik motorik: dengan melakukan aktivitas bermain, membuat anak menggerakkan dan melatih seluruh otot yang ada di badannya, sehingga anak cakap dalam melakuka kegiatan yang yang terkait dengan motoric, dan peka ketika menggunakan alat inderanya. Focus utama dalam permainan adalah anak mampu melakukan koordinasi gerakan yang menggunakan motoric kasar maupun motoric halus. Hal tersebut bisa dilihat dari kegiatan anak yang dilakukan secara berulang dan terus menerus, misalnya lari, memanjat, dll. Dalam permainan monyet dan pohon, anak mampu menggunakan otot besar untuk bergerak dengan lincah. Seperti yang diketahui pada permainan ini anak belajar menjadi cekatan dalam berpindah atau bergerak kesana kemari.

3. Bahasa: Dalam kegiatan bermain, terdapat berbagai macam kata yang digunakan oleh anak. Tujuannya adalah untuk melatih komunikasi pada anak. Ketika bermain, anak harus mengerti apa yang dikomunikasikan oleh anak yang lainnya. Ketika melakukan permainan monyet dan pohon, anak mampu menyimak perintah yang diberikan dan melakukan 2-3 perintah bersamaan. Ketika guru memberi instruksi monyet atau pohon bila anak kesulitan dalam menyimak maka informasi yang didapat tidak akan benar. Anak mungkin hanya akan diam atau salah berpindah tempat. Anak juga mampu mengembangkan kemampuan komunikasinya dengan cara bercakap-cakap dengan temannya.

4. Sosial emosional: Dengan bermain, anak belajar untuk menjalin hubungan baik dengan teman sebanyanya. Pembelajaran yang dapat diterima oleh anak ketika bermain seperti mengalah, memberi, menerima, menolong, dan berbagai perilaku social lainnya. Selain itu, anak juga belajar untuk mengendalikan emosinya ketika berinteraksi dengan lingkungan sosialnya. Anak juga dapat berekspresi dan menjadi salah satu terapi pada anak yang mengalami gangguan emosi. Dalam permainan monyet dan pohon, anak mampu bermain bersama dan 
bekerja sama dengan teman. Karena dalam permainan monyet dan pohon ini bisa dimainkan minimal 2 kelompok yaitu terdiri dari 6 anak.

5. Seni: anak mampu mengekspresikan peran. Dalam permainan monyet dan pohon misalnya sebagai monyet atau pohon dalam permainan.

6. Moral dan agama: Melalui kegiatan bermain, banyak hal yang bisa dipelajari oleh anak, misalnya dengan lapang dada mau menerima kekalahan, belajar memimpin teman-temannya, dll. Jika anak gagal di dalam suatu permainan, anak akan belajar menerimanya dan bertanggung jawab atas apa yang telah dilakukannya. Selain itu, dalam berinteraksi dengan teman-temannya ketika bermain, anak juga akan belajar bekerja sama, jujur, dll. Dalam permainan monyet dan pohon, anak mampu menghormati dan menghargai teman, ketika teman dalam satu tim ingin menjadi pohon atau monyet, anak harus mau menerima peran lain dan bersabar untuk menerima peran yang lain secara bergantian.

Konvensi Hak Anak PBB (1989) menegaskan bahwa bermain adalah salah satu hak anak. Oleh karena itu, tidak mengijinkan anak bermain adalah sesuatu yang tidak benar. Sebaliknya baik orangtua ataupun guru akan lebih baik bila menggunakan karakteristik alami anak sebagai cara belajar yang menyenangkan.

Dworetzky dalam Moeslichatoen juga mengemukakan bahwa kegunaan bermain dan interaksi dalam permainan memiliki peranan yang penting untuk perkembangan kognitif dan sosial anak, selain itu fungsi bermain dapat meningkatkan perkembangan bahasa, disiplin, perkembangan moral, kreativitas dan perkembangan fisik anak. Melalui bermain aspek-aspek perkembangan anak akan banyak terlatih, hal ini disebakan dalam bermain terjadi sebuah interaksi yang kompleks dimana anak akan mendorong keluar semua kemampuan dalam dirinya.

\section{KESIMPULAN}

Permainan monyet dan pohon merupakan permainan yang menyenangkan dan mudah untuk diterapkan pada anak usia dini khususnya yang sudah berusia 5-6 tahun. Karena pada usia 5-6 tahun anak sudah mampu untuk memahami aturan. Kemampuan bahasanya juga sudah baik begitu pula dengan kematangan emosinya yang sudah berkembang. Dari Permainan pohon dan monyet ini anak dapat belajar mengembangkan kemampuannya dan mendapatkan stimulus yang tepat pada aspek agama dan moral, fisik motoric, kognitif, Bahasa, sosial emosional dan seni.

\section{DAFTAR PUSTAKA}

Ailwood, Jo. 2003. Governing Early Childhood Education Through Play. Contemporary Issues in Early Childhood. 4 (3) 286-299

Arumsari, Andini Dwi., Arifin, Bustomi., dan Rusnalasari, Zulidyana Dwi. (2017). Pembelajaran Bahasa Inggris pada Anak Usia Dini di Kecamatan Sukolilo Surabaya. Jurnal PG PAUD Trunojoyo, Vol 4 No 2 Oktober 2017.

Bateson, G., \& Mead, M. (1942). Balinese character: A photographic analysis. New York: New York Academy of Sciences. 
Fauziddin, M. (2016). Peningkatan Kemampuan Kerja Sama melalui Kegiatan Kerja Kelompok Pada Anak Kelompok A TK Kartika Salo Kabupaten Kampar. Jurnal Obsesi $\square$ : Jurnal Pendidikan Anak Usia Dini, 2(1).

Indonesia, R. Undang-Undang Nomor 20Tahun 2003, 41 (2003).

M. Fadhillah, M. (2017). Bermain dan Permainan. Jakarta: Prenadamedia group.

Pratiwi, Wiwik. (2017). Konsep Bermain Pada Anak Usia Dini. Institut Agama Islam Negeri Sultan Amai Gorontalo

Santrock, J. W. (2002). A Topical approach to life-span development. Jakarta: Erlangga.

Sari, Anisa Yunita., dan Arumsari, Andini Dwi. (2019). Metode Eksperimen Media Air untuk Perkembangan Sosial Anak Usia Dini. Pedagogi: Jurnal Anak Usia Dini dan Pendidikan Anak Usia Dini, Volume 5 Nomor 1 Volume 2019, P-ISSN: 2599-0438; E-ISSN: 2599-042X.

Widyastuti, Susana. (2010). Belajar Sambil Bermain:Metode Mendidik Anak Secara Komunikatif. Klaten: Sekolah Taruna Bangsa. 


\title{
PENERAPAN APPLIKASI EDUKASI KOMPUTER UNTUK MENINGKATKAN HAPALAN ABJAD DI TK YAPITA SURABAYA
}

\author{
${ }^{1}$ Lianatus Shofia, ${ }^{2}$ Valentine Aqwarinna Gempita, ${ }^{3}$ Nopitasari, ${ }^{4}$ Muchamad Arif \\ ${ }^{1,2,3}$ Fakultas Keguruan dan Ilmu Pendidikan, Universitas Narotama \\ ${ }^{4}$ Fakultas Ekonomi dan Bisnis, Universitas Narotama \\ 4 muchamad.arif@narotama.ac.id
}

\begin{abstract}
ABSTRAK
Penelitian ini bertujuan untuk mengetahui keefektifitasan applikasi edukasi yang diterapkan di TK Yapita Surabaya. Penulis menggunakan metode deskriptif qualitative. Penulis focus bagaimana menerapkan applikasi edukasi komputer dalam membantu siswa menghapal abjad. Penulis melakukan observasi selama 3x pertemuan. Setiap pertemuan, mereka mendapatkan permainan applikasi edukasi computer yang berbeda namun isi materinya sama. Applikasi tersebut sudah terinstal di setiap computer sekolah yang sudah disesuaikan dengan materi yang diajarkan. Subjek penelitian adalah TK A yang berjumlah 30 siswa. Setiap siswa menggunakan computer yang disediakan di setiap pertemuan selama 30 menit. Hasil penelitian menunjukkan bahwa media pembelajaran melalui program komputer yang bervariasi dalam suatu permainan akan membuat anak-anak semakin bersemangat dan antusias untuk belajar karena tidak membosankan. Namun, bagi anak-anak yang kurang memahami urutan abjad, mereka akan mengalami kesulitan dan kebingungan. Serta, anak yang memiliki fisik motoriknya kurang terlatih akan mengalami kesulitan pada saat menggunakan mouse.
\end{abstract}

Kata Kunci: applikasi computer, abjad, antusias, motorik halus

\begin{abstract}
This study aims to determine the effectiveness of the educational application that is applied in Yapita Kindergarten Surabaya. The author uses descriptive qualitative methods. The author focuses on how to apply computer education applications to help students memorize the alphabet. The author made observations during the $3 \mathrm{x}$ meeting. Each meeting, they get a different computer education application game but the contents of the material are the same. The application has been installed on every school computer that has been adapted to the material being taught. The subject of the research was TK A, amounting to 30 students. Each student uses the computer provided at each meeting for 30 minutes. The results showed that learning media through varied computer programs in a game will make children more excited and enthusiastic to learn because it is not boring. However, for children who do not understand the alphabetical order, they will experience difficulties and confusion. Also, children who have poorly trained physics will experience difficulties when using the mouse.
\end{abstract}

Keywords: : computer application, alphabetical, enthusiastic, soft motoric 


\section{PENDAHULUAN}

Media pembelajaran berbasis ICT yang di terapkan di TK YAPITA dalam pengajaran melalui media komputer. Dengan media tersebut diharapkan dapat tercapainya tujuan yang telah dirumuskan dalam pembelajaran baik tujuan kognitif, afektif atau aspek-aspek perkembangan lainnya, karena media tersebut sangat efektif, menarik, serta dapat menstimulasi pikiran karena membantu anak usia dini dari berpikir abstrak ke berpikir konkret.

Dari penerapan media berbasis ICT ini dapat meningkatkan atau mengembangkan semua aspek perkembangan. Dari aspek kognitif anak-anak dapat mengenal konsep dan mengklasifikasikan serta memecahkan masalah lalu mengkomunikasikan apa yang anak pahami seperti anak mengenal konsep bentuk geometri serta mengklasifikasikan bentukbentuk geometri, mengurutkan angka, mengenal angka dll. Dari aspek fisik motorik, anak dapat melatih motorik halusnya pada waktu menggunakan mouse komputer sehingga jari-jari tangan terkoordinasi.

Dari aspek bahasa pembelajaran berbasis ICT ini dapat menambah kosa kata pada waktu terjadi komunikasi ketika muncul rasa ingin tahu anak sehingga timbul pertanyaan entah ke sesama teman atau pada para pendidik selain itu pembelajaran ini dapat mengenalkan abjad menjadi kata. Dari aspek sosial emosional, anak dapat mengekspresikan emosinya dari permainan yang dia kerjakan selain itu dapat mengolah emosinya pada saat pembelajaran. Dengan media komputer juga dapat mengembangkan sosial anak ketika dia terjadi tanya jawab antar teman, saling memberi semangat dan berbagi tempat dan lain-lain.

Aspek seni, anak-anak dapat menghargai hasil yang di buat dari pembelajaran komputer dan menyukai keindahan atau estetis, dapat memainkan warna-warna dan lain-lain. Aspek NAM, anak ketika masuk ruangan komputer bersikap sopan dan salam serta mematuhi perintah para pendidik, menghargai teman dan saling toleransi antar teman, jujur dalam mengerjakan tugas, disiplin dan lain-lain.

\section{METODE PENELITIAN}

Penelitian ini dilaksanakan di TK YAPITA Surabaya. Sekolah ini terletak di Jl. Keputih III/6 Surabaya. Penelitian ini dilaksanakan selama 3x yakni pada hari selasa 9 April 2019, kamis 11 April 2019, dan selasa 16 April 2019. Subjeknya adalah siswa TK A yang berjumlah 30, 14 siswa laki-laki dan 16 siswa perempuan. Jenis penelitian ini adalah deskriptif kualitati karena metode yang digunakan untuk memecahkan masalah yang sedang dihadapi pada situasi sekarang (Ary: 1985, Azwar: 1999, Sukardi: 2004). Materi yang digunakan adalah mengurutkan abjad. Sumber data yang digunakan adalah kegiatan murid ketika menggunakan applikasi edukasi computer untuk mengurutkan abjad. Sedangkan data yang diambil adalah hasil belajar siswa dengan menggunakan applikasi edukasi computer. Setiap computer di TK Yapita sudah mempunyai applikasi edukasi sendiri di dalamnya. Sehingga para guru tidak perlu menginstal applikasi edukasi sendiri. 


\section{HASIL DAN DISKUSI}

Penelitian ini dilaksanakan selama 3x. Siswa selalu belajar tentang abjad terutama mengurutkan abjad setiap pertemuan. Setiap pertemuan mereka belajar menghapal abjad namun setiap pertemuan mempunyai permainan hapalan abjad yang berbeda di komputer sehingga mereka lebih antusias dalam mengahapal semua abjad. Untuk kegiatan dan hasil penelitian akan dijelaskan seperti di bawah ini.

Pada kegiatan awal, anak-anak biasanya berkumpul. Mereka membuat lingkaran. Kemudian, guru melakukan presensi terlebih dahulu. Selanjutnya, guru menjelaskan materi-materi yang akan dipelajari yakni tentang mengenal abjad. Kemudian, anak-anak diberi buku kerja siswa atau pemberian tugas supaya anak-anak semakin memahami penjelasan yang sudah diterima.

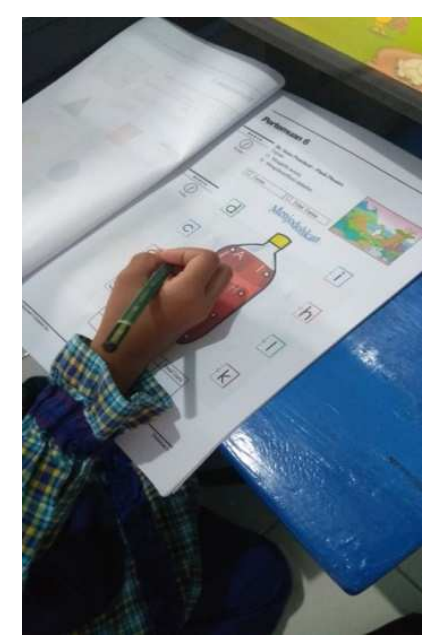

Gambar 1. buku kerja siswa

Selanjutnya pada kegiatan inti, guru mengarahkan anak-anak pada komputer yang sudah disediakan. Kemudian, anak-anak bermain permainan yang sudah tersedia pada program komputer tersebut. Setiap pertemuan, mereka mendapatkan variasi permainan menghapal abjad. Berikut ini adalah salah satu permainan mengurutkan abjad di computer sekolah. 


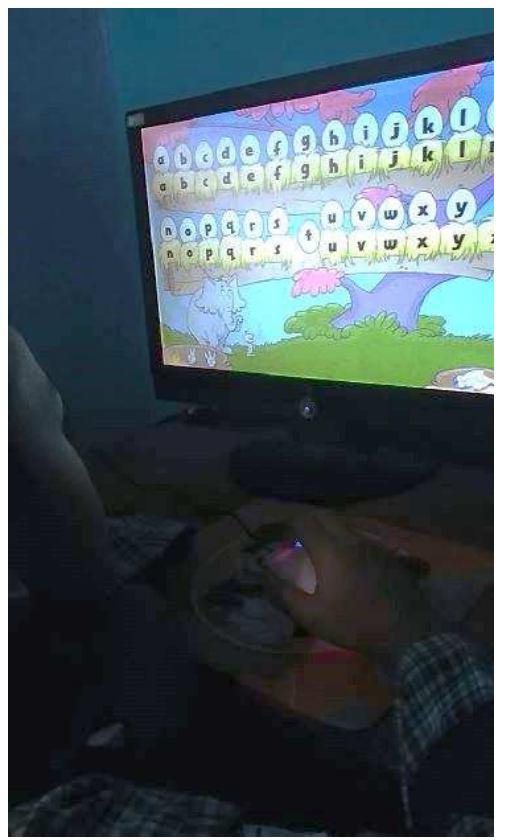

Gambar 2. Permainan mengurutkan abjad

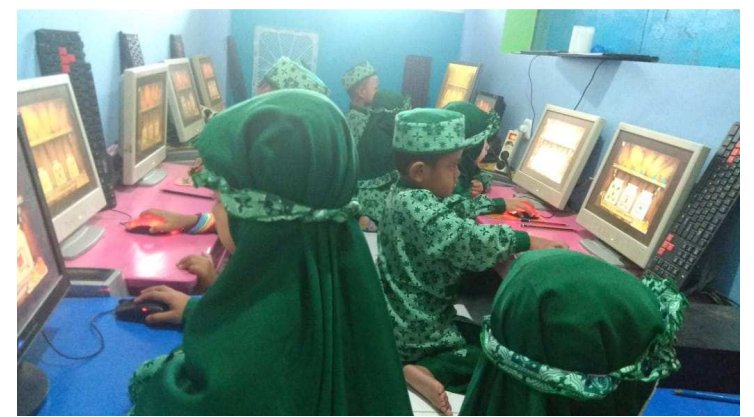

Gambar 3. Siswa mengerjakan permaina mengurutkan abjad

Pada akhir kegiatan, guru biasanya mereview kegiatan pada hari itu. Guru menanyakan perasaan anak-anak setelah melakukan kegiatan pembelajaran tersebut apakah senang, gembira, atau mengalami kesulitan. Serta, guru memberikan motivasi agar anak-anak semakin bersemangat dalam belajar.

Berdasarkan uraian kegiatan di atas, penulis menganalisa kelebihan dan kekurangan penerapan applikasi edukasi computer. Dengan menggunakan media pembelajaran melalui program komputer yang bervariasi dalam suatu permainan, anak-anak semakin bersemangat dan antusias karena tidak membosankan. Selain itu, kegiatan ini dapat mengembangkan semua aspek perkembangan seperti aspek kognitif, sosial emosional, fisik motorik, nilai agama dan moral, seni, serta bahasa. Bahkan, kegiatan ini juga dapat melatih fokus anak.

Dengan menggunakan computer, anak-anak semakin bersemangat dalam belajar serta memunculkan imajinasi anak yang membuat kognitif semakin berkembang. Bahkan, kegiatan ini merupakan hal yang menyenangkan bagi anak-anak. Kegiatan ini juga bisa melatih kepercayaan diri pada anak karena anak dapat menyelesaikan tugasnya secara mandiri dan menghargai keberhasilan yang ia capai. 
Di sisi lain, bagi anak-anak yang kurang memahami abjad atau kurang mengenal urutan abjad akan mengalami kesulitan dan kebingungan. Serta, anak yang fisik motoriknya kurang terlatih akan mengalami kesulitan pada saat menggunakan mouse. Dalam hal ini, guru harus tetap memberikan bimbingan agar dapat memaksimalkan pembelajaran.

\section{KESIMPULAN}

Penerapan pembelajaran berbasis ICT sangat bermanfaat diantaranya membantu anak-anak dalam proses belajar karena pembelajaran berbasis ICT adalah pembelajaran yang menarik dan juga mudah di pahami oleh anak. Bahka, media ini dapat meningkatkan fokus pada anak. Selain itu, pembelajaran berbasis ICT juga dapat meningkatkan perkembangan di semua aspek perkembangan anak, yaitu aspek kognitif, sosial emosional, fisik motorik, nilai agama dan moral, seni, serta bahasa. Di sisi lain, guru juga harus bisa mengembangkan motoric halus anak. Apabila anak mengklik mouse, mereka bisa mengklik dengan sesuai dan benar. Hal ini juga akan berdampak pada kegiatan proses pembelajaran yang lain. 


\section{DAFTAR PUSTAKA}

Ary, Donald. 1985. Introduction to Research In Education. New York:CBS College Publishing Azwar, Saifuddin. 1999. Metode Penelitian. Yogyakarta : Pustaka Pelajar

Sukardi, 2004. Metode Penelitian Pendidikan. Jakarta: Bumi Aksara 